\title{
The blue suns of 1831: was the eruption of Ferdinandea, near Sicily, one of the largest volcanic climate forcing events of the nineteenth century?
}

\author{
Christopher Garrison, Christopher Kilburn, David Smart, and Stephen Edwards \\ UCL Hazard Centre, Department of Earth Sciences, University College London, Gower Street, London WC1E 6BT, UK \\ Correspondence: Christopher Garrison (c.garrison@ucl.ac.uk)
}

Received: 24 June 2021 - Discussion started: 5 August 2021

Accepted: 1 November 2021 - Published: 20 December 2021

\begin{abstract}
One of the largest climate forcing eruptions of the nineteenth century was, until recently, believed to have taken place at the Babuyan Claro volcano, in the Philippines, in 1831. However, a recent investigation found no reliable evidence of such an eruption, suggesting that the 1831 eruption must have taken place elsewhere. We here present our newly compiled dataset of reported observations of a blue, purple and green sun in August 1831, which we use to reconstruct the transport of a stratospheric aerosol plume from that eruption. The source of the aerosol plume is identified as the eruption of Ferdinandea, which took place about $50 \mathrm{~km}$ off the south-west coast of Sicily $\left(37.1^{\circ} \mathrm{N}, 12.7^{\circ} \mathrm{E}\right)$, in July and August 1831. The modest magnitude of this eruption, assigned a volcanic explosivity index (VEI) of 3, has commonly caused it to be discounted or overlooked when identifying the likely source of the stratospheric sulfate aerosol in 1831. It is proposed, however, that convective instability in the troposphere contributed to aerosol reaching the stratosphere and that the aerosol load was enhanced by addition of a sedimentary sulfur component to the volcanic plume. Thus, one of the largest climate forcing volcanic eruptions of the nineteenth century would effectively have been hiding in plain sight, arguably "lowering the bar" for the types of eruptions capable of having a substantial climate forcing impact. Prior estimates of the mass of stratospheric sulfate aerosol responsible for the 1831 Greenland ice core sulfate deposition peaks which have assumed a source eruption at a low-latitude site will, therefore, have been overstated. The example presented in this paper serves as a useful reminder that VEI values were not intended to be reliably correlated with eruption sulfur yields unless supplemented with compositional analyses. It also underlines that eye-witness accounts
\end{abstract}

of historical geophysical events should not be neglected as a source of valuable scientific data.

\section{Introduction}

Volcanic eruptions that produce sulfate aerosols in the stratosphere are important climate forcing events (Robock, 2000). Ranked in order of the mass of stratospheric sulfate aerosol produced, the most important climate forcing volcanic eruptions of the nineteenth century are as follows: Tambora, in Indonesia, in $1815(120 \mathrm{Tg})$; an unidentified eruption in 1809 (59 Tg); Cosegüina, in Nicaragua, in 1835 (40 Tg); Krakatoa, in Indonesia, in 1883 (27 Tg); and another unidentified eruption in 1831 (17 Tg) (Gao et al., 2008). The combination of the 1831 eruption and the 1835 Coseguiina eruption contributed to delaying the end of the Little Ice Age and, hence, the onset of modern anthropogenic warming, until 1850 (Brönnimann et al., 2019). Until recently, the 1831 eruption had commonly been assumed to be an eruption of Babuyan Claro, in the Philippines, which had notionally been assigned a volcanic explosivity index (VEI) of 4 (Zielinski, 1995; Global Volcanism Program, 2013; Arfeuille et al., 2014; Toohey and Sigl, 2017). However, Garrison et al. (2018) found no reliable evidence of such an eruption in 1831, suggesting that the climate forcing eruption must have taken place elsewhere.

Observations of a blue, purple and green sun occurred around the world in August 1831 (Arago, 1832; Kiessling, 1888; Symons et al., 1888). The sun is white when viewed from above Earth's atmosphere. At Earth's surface, however, its observed colour varies due to scattering and absorption 
by atmospheric gases and aerosols (Bohren and Huffman, 2004). A sufficiently dense aerosol of solid particles or liquid droplets with a radius of about $0.5 \mu \mathrm{m}$, and a refractive index of about 1.5 may alter the observed colour of the sun to a pronounced blue, purple or green (La Mer and Kerker, 1953; Penndorf, 1953; Van de Hulst, 1981; Porch, 1989; Horvath et al., 1994; Ehlers et al., 2014; Wullenweber et al., 2021). Such an aerosol is occasionally produced by a volcanic eruption, such as the 1880 eruption of Cotopaxi in Ecuador (Whymper, 1884 ) or the 1883 eruption of Krakatau in Indonesia (Symons et al., 1888), or by a forest fire, such as the 1950 Chinchaga fire in Canada (Bull, 1951; Wilson, 1951). For as long as an aerosol maintains these parameters whilst being transported in the atmosphere, it will produce a sequence of observations of a blue, purple or green sun at different dates and places. Consequently, a sequence of reported observations of a blue, purple or green sun may be used to reconstruct the atmospheric transport of the aerosol responsible, potentially tracing it back to its source (Symons et al., 1888).

Here, we present our newly compiled dataset of reported observations of a blue, purple and green sun in August 1831, which we use to reconstruct the transport of a stratospheric aerosol plume from the 1831 eruption. We are thus able to constrain the location of the eruption to a mid-latitude site between 30 and $45^{\circ} \mathrm{N}$. Using additional reports where a blue, purple or green sun was not seen, despite active observation, we are also able to constrain its longitude and, hence, identify it as the eruption of Ferdinandea, which took place about $50 \mathrm{~km}$ off the south-west coast of Sicily $\left(37.1^{\circ} \mathrm{N}, 12.7^{\circ} \mathrm{E}\right)$ in July and August 1831. The modest magnitude of this eruption, assigned a VEI of 3 (Global Volcanism Program, 2013), i.e. 10 times smaller in terms of the volume of ejected material than a VEI of 4, has commonly caused it to be discounted or overlooked when identifying the likely source of the stratospheric sulfate aerosol in 1831 (Camuffo and Enzi, 1995; Zielinski, 1995; Robertson et al., 2001, Arfeuille et al., 2014; Toohey and Sigl, 2017). However, we hypothesize that convective instability in the troposphere contributed to aerosol reaching the stratosphere and that the aerosol load was enhanced by addition of a sedimentary sulfur component to the volcanic plume.

\section{Methodology}

For simplicity, we use the term "blue $e^{(+)}$" to include the colours blue, purple and green. A literature search was undertaken to collect as many reported observations of a blue ${ }^{(+)}$ sun in 1831 as possible. The observations compiled by Arago (1832), Kiessling (1888) and Symons et al. (1888) were traced, as far as possible, to their primary sources. Additional primary sources were identified using a combination of "structured" searches (e.g. reviewing obviously relevant national and local newspapers, scientific journals, and collections of published accounts of travel and residence) and "unstructured" searches (e.g. keyword searches of digital archives). A minimum requirement was that a blue ${ }^{(+)}$ sun was observed at least once during the day and that the date and place of the observation was recorded. To determine the boundaries of the region in which a blue ${ }^{(+)}$sun was observed, the search also extended to reports recording active observation but without a blue ${ }^{(+)}$sun having been seen ("null" observations). Most of the source materials studied were originally written in western European languages, although at least some were originally written in Arabic, Mandarin and Russian. Online search engines facilitated access to relevant historical materials and translation tools. Supplemental searches of non-digital archives at, for example, the Observatoire de Paris, the Osservatorio Astronomico di Palermo and the British Library were also undertaken. In the course of the search, reported observations of other unusual atmospheric optical phenomena in 1831 were noted and collected and will be referred to in this paper as appropriate.

\section{Results}

\subsection{Reported observations}

Thirty one primary sources reporting observations of a blue $^{(+)}$sun are summarized in Appendix A. The text of three representative reports is reproduced in Table 1. Fifteen of these sources had been identified in Arago (1832), Kiessling (1888) and Symons et al. (1888), but the remaining sixteen are newly identified here. Seventeen primary sources reporting null observations are also summarized in Appendix B. The original language of the sources in Appendices A and B is English (60\%), French (17\%), Italian $(8 \%)$, German (6\%), Spanish (4\%), Catalan (2\%) and Arabic (2\%). By type, they comprise newspaper reports (35\%), published accounts of travel and residence ( $25 \%)$, observational (meteorological) registers published in newspapers or scientific journals (19\%), communications to learned societies published in scientific journals $(15 \%)$, letters to newspapers $(4 \%)$, and other published records $(2 \%)$.

The reported blue ${ }^{(+)}$sun observations took place between 3 August 1831 (source [A1]) and around 28 August 1831 (source [A31]) in Europe, the Caribbean, the north Atlantic, the USA and China (Fig. 1). The sites were located at latitudes between 19 and $47^{\circ} \mathrm{N}$, although about $85 \%$ were restricted to between 30 and $45^{\circ} \mathrm{N}$ (Figs. 1, 2). The locations of the sites are evidently biased toward regions which had comparatively high population densities in 1831 and, moreover, populations which were likely to report observations in a form which remains accessible today, in particular in Europe and on the eastern coast of the USA. Carpenter (1884) reports that a blue sun was seen "at Washington", in the USA, in "October, especially October $12 \ldots$ [and]... October $13 \ldots$ "1831. However, this appears to be the result of an erroneous conflation between the date and place of an observation on 12 and 13 August 1831 in Alexandria, Virginia, about $10 \mathrm{~km}$ 
Table 1. Three representative reported observations of a blue ${ }^{(+)}$sun in 1831.

\begin{tabular}{|c|c|c|c|}
\hline $\begin{array}{l}\text { Source } \\
\text { no. }\end{array}$ & Date & Place & Text \\
\hline A5 & $8 / 8 / 1831$ & $\begin{array}{l}\text { Palermo, } \\
\text { Sicily, } \\
\text { Italy }\end{array}$ & $\begin{array}{l}\text { "Dalle } 6 \text { in poi il sole attraversa le dense nebbie presentava un disco con una placida luce } \\
\text { bianca turchina; al tramontare lasciò verso ponente una luce rossastra che si prolungò sino a } \\
\text { sera avanzata." (Cacciatore, 1831b). } \\
\text { Translation (author's own): from 18:00 LT onward, the sun observed through the dense fog } \\
\text { appeared as a pale whitish-blue disc; a reddish light to the west after sunset lasted until late in } \\
\text { the evening. }\end{array}$ \\
\hline A 10 & $10 / 8 / 1831$ & $\begin{array}{l}\text { Saint-Sever, } \\
\text { Nouvelle- } \\
\text { Aquitaine, } \\
\text { France }\end{array}$ & $\begin{array}{l}\text { “... vers cinq heures du soir... Le soleil était rond et blanc comme une lune, c'est à dire qu'il } \\
\text { était dépourvu de rayons apparens, et qu'on pouvait le regarder en face sans que la vue en fût } \\
\text { nullement offensée. Une heure après, cet astre était d'un bleu pâle décidé, toujours dépourvu de } \\
\text { rayonnement, et l'horizon de son coucher était d'un rouge vif, comme cela s'observe } \\
\text { fréquemment dans les journées chaudes. Une sorte de brume éloignée de la terre, et de densité } \\
\text { différente, était uniformément répandue dans les régions supérieures, et voilait l'astre du jour... } \\
\text { Dans la journée, on avait remarqué que les objets éclairés par les rayons à nu du soleil avaient } \\
\text { une teinte bleuâtre.” (Dufour, 1831). } \\
\text { Translation: “... about five o'clock in the afternoon... the sun appeared round and white like } \\
\text { a moon; that is to say, it emitted no apparent rays, and could be steadfastly regarded without } \\
\text { dazzling or in any manner affecting the eyes. An hour afterwards, it appeared of a pale blue } \\
\text { colour, but still destitute of rays; and the horizon, at its setting, was of a deep red, such as is } \\
\text { frequently observed after a very hot day. A kind of mist, at a considerable distance from the } \\
\text { earth, and of trifling density, was uniformly spread in the upper regions of the atmosphere, and } \\
\text { veiled the sun... During the day, the objects exposed to the direct rays of the sun had been } \\
\text { observed to assume a blueish tint.” (London and Paris Observer, 1831). }\end{array}$ \\
\hline A22 & $\begin{array}{l}13 / 8 / 1831 \\
14 / 8 / 1831\end{array}$ & $\begin{array}{l}\text { Norfolk, } \\
\text { Virginia, } \\
\text { USA }\end{array}$ & $\begin{array}{l}\text { "We have all seen the sun of a dusky red or copper color; but who, until Saturday, the 13th of } \\
\text { this month, ever saw it clad in sky blue and pea green? On Saturday, and yesterday morning at } \\
\text { its rising, it was of a light but lively green, and as it ascended above the horizon, changed first } \\
\text { to cerulean, then to silver white, and finally to pale yellow, when its beams no longer permitted } \\
\text { the intrusive gaze of the multitude. And so in its decline, about } 5 \text { o'clock in the afternoon it } \\
\text { appeared like a globe of silver through the thick haze which overspread the Heavens, shorn of } \\
\text { its beams, and gradually assumed the cerulean tint, from which it passed to a light green. A } \\
\text { black spot near the centre, was discernible by the naked eye, apparently of the size of a walnut, } \\
\text { and with a good spy glass, two others were distinctly visible. In an hour after the sun had set, } \\
\text { the horizon in the Northwest exhibited a glare of ruddy light, bearing a strong resemblance to } \\
\text { the reflection of a large fire." (Washington National Intelligencer, 1831). }\end{array}$ \\
\hline
\end{tabular}

from Washington (source [A18]), and the publication of this observation in the October edition of Niles' Weekly Register (1831).

Additional observations of blue ${ }^{(+)}$sunlight in China in the summer of 1831 are reported in a Mandarin-language compendium of meteorological records (Zhang, 2004). However, this compendium is itself based on an earlier compendium, and the primary sources are not available. These observations have accordingly not been included in the present analysis.

\subsection{A sequence of observations of a blue ${ }^{(+)}$sun}

The reported observations of a blue ${ }^{(+)}$sun in 26 of the 31 sources (Appendix A) form a connected sequence. The earliest observation in the sequence is that reported in Palermo, Sicily, Italy $\left(38.1^{\circ} \mathrm{N}, 13.4^{\circ} \mathrm{E}\right)$, at 18:00 LT on 8 August 1831 (source [A5]; Fig. 3a). Over the following 9d, the loca- tions of the observations move westward, from Europe to the USA, as well as spreading to the north and south, largely across the $30-45^{\circ} \mathrm{N}$ latitude band, although occasionally further north (to about $50^{\circ} \mathrm{N}$; source [A12]) and further south (to about $20^{\circ} \mathrm{N}$; source [A19]) (Figs. 3b-j, 4). The observations reported around 28 August 1831 (source [A31]) plausibly extend the connected sequence further westward to China (Fig. 4).

At locations to the east of Sicily from Malta to India, including those across the $30-45^{\circ} \mathrm{N}$ latitude band, the sources identified reported null observations, i.e. despite observations being actively recorded, no blue ${ }^{(+)}$sun was seen (Appendix B; Fig. 5). (The apparently exceptional case of the observation reported in Odessa, Ukraine (source [A7]; Fig. 5) is discussed in Sect. 4.1.) The same was true for locations further north and north-west of Sicily from northern Italy, 


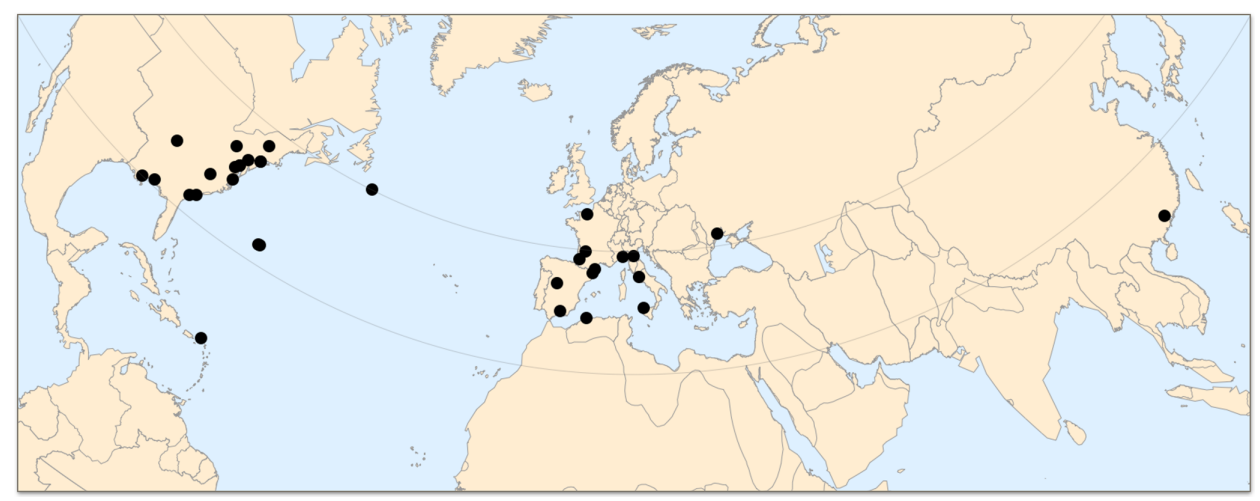

Figure 1. Location of blue ${ }^{(+)}$sun observations reported in August 1831 (Appendix A). The latitude band shown extends from 30 to $45^{\circ} \mathrm{N}$. National borders are shown as correct for 1831 (based on data from Mathematica v. 12.0, Wolfram Research).

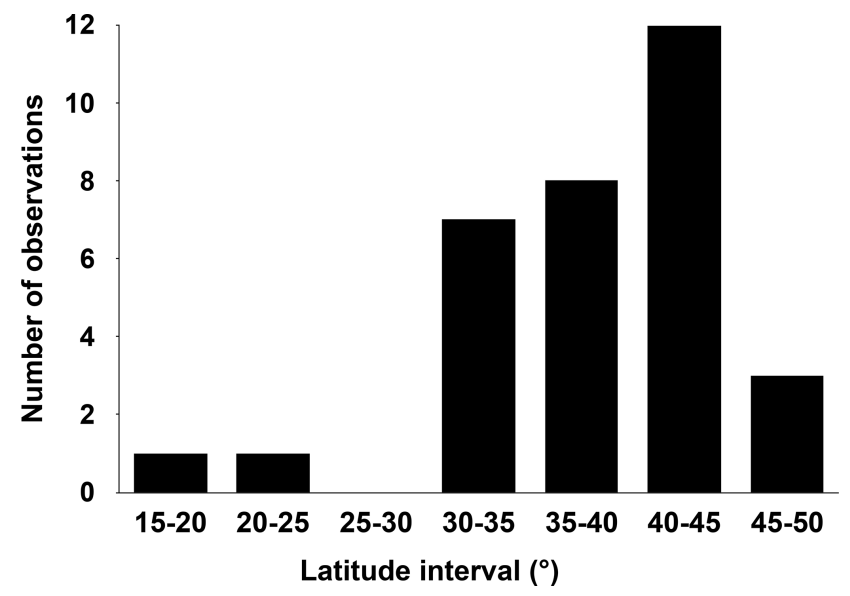

Figure 2. Number of blue ${ }^{(+)}$sun observations reported in August 1831 in different latitude bands (Appendix A).

Switzerland, Hungary and Germany to the UK (Appendix B; Fig. 5). No reported observations could be found from locations to the south or south-west, across the Sahara Desert. On this basis, the eastern boundary of the region in which the observation of a blue ${ }^{(+)}$sun was reported in August 1831 can be delineated approximately by the A-A' curve in Fig. 5 .

\subsection{Reconstruction of aerosol transport}

Given the geographical and temporal distribution of these blue $^{(+)}$sun observations, we propose the following approximate reconstruction of the transport of the aerosol responsible. The aerosol source must have been located in the vicinity of Sicily, near the intersection of the A-A' curve with the centre of the $30-45^{\circ} \mathrm{N}$ latitude band (Fig. 5). It caused aerosol to be formed between 8 and 13 August 1831 at an altitude with atmospheric circulation from east to west, such that a plume of aerosol lengthened to the west of Sicily (Fig. 6a-f). On 13 August 1831, the aerosol plume extended between about $15^{\circ} \mathrm{E}$ and $90^{\circ} \mathrm{W}$ in longitude, over an area of about $14000000 \mathrm{~km}^{2}$ in the latitude band between 30 and $45^{\circ} \mathrm{N}$ (Fig. 6f; Table 2). Once the source had ceased to cause the formation of aerosol at that altitude, around 14 August 1831, the "detached" aerosol plume continued to be transported westward (Fig. $6 \mathrm{~g}-\mathrm{j}$ ) eventually reaching China around 28 August 1831.

\subsection{Aerosol transport velocity}

Calculating the elapsed time between the earliest and latest progressively further westward blue ${ }^{(+)}$sun observations from 8 to 17 August 1831 in the latitude band $40 \pm 2^{\circ} \mathrm{N}$ (Appendix A) yields a transport rate of about $0.97^{\circ}$ (long.) $\mathrm{h}^{-1}$ for the leading edge of the aerosol plume and about $0.73^{\circ}$ (long.) $\mathrm{h}^{-1}$ for its trailing edge (Fig. 7). Taking the mean transport rate of $0.85^{\circ}$ (long.) $\mathrm{h}^{-1}$ at $40^{\circ} \mathrm{N}$ yields a linear velocity of about $20 \mathrm{~m} \mathrm{~s}^{-1}$.

\subsection{Aerosol transport altitude}

The prevailing winds in the mid-latitude upper troposphere in the Northern Hemisphere are westerly (Barry and HallMcKim, 2014). As the aerosol plume transport took place from east to west, it must have been transported at an even higher altitude, above the tropopause. The source event type is most plausibly either a volcanic eruption or a very large forest or bush fire, either of which can inject aerosol into the stratosphere (Robock, 2000; Khaykin et al., 2020); supereruptions with a VEI of 7 or more may even inject aerosol into the mesosphere (Costa et al., 2018). Given that a supereruption in the vicinity of Sicily in August 1831 could not have gone un-recorded, however, it is reasonable to assume that the aerosol plume must have been transported in the stratosphere. An easterly stratospheric wind direction at around $40^{\circ} \mathrm{N}$ in July is also supported by zonal mean wind fields derived from twentieth-century data (Randel, 2003). 

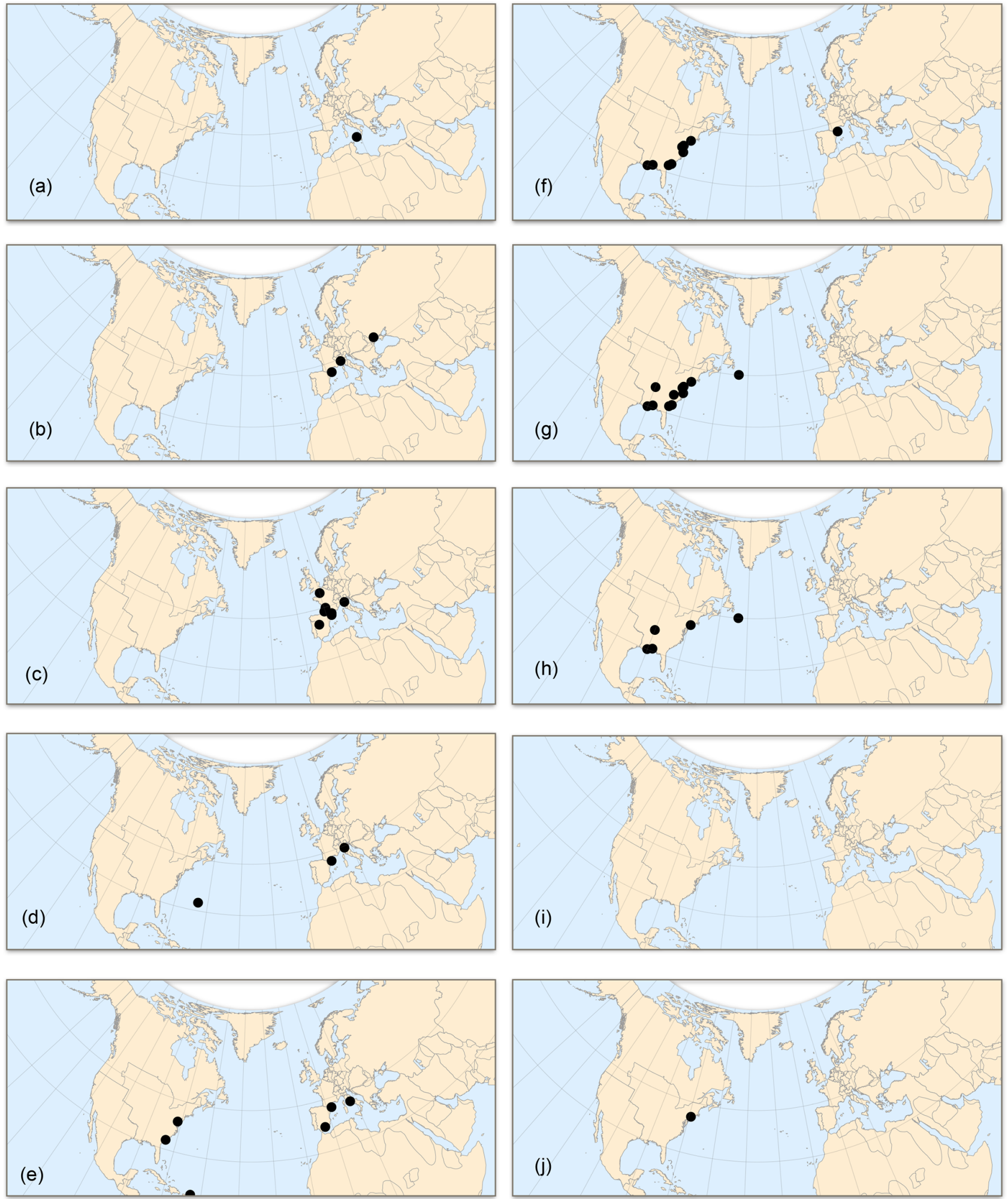

Figure 3. (a-j) Progression of observations of a blue ${ }^{(+)}$sun reported between 8 and 17 August 1831 (Appendix A). The sequence of observations runs day by day from 8 August (a) to 12 August (e) and from 13 August (f) to 17 August (j). No reported observations of a blue $^{(+)}$sun have been identified on 16 August (i). 
Table 2. Parameters for use with Eq. (2) in Sect. 3.6.

\begin{tabular}{|c|c|c|}
\hline Parameter & $\begin{array}{l}\text { Approximate } \\
\text { value }\end{array}$ & Rationale \\
\hline $\begin{array}{l}\text { Extinction } \\
\text { efficiency }(Q)\end{array}$ & 2 & $\begin{array}{l}\text { As an approximation to Mie's (1908) rigorous description, Van de Hulst (1981) } \\
\text { describes the extinction of light of wavelength } \lambda \text { by idealized spherically symmetric } \\
\text { particles with radius } r \text { and (real) refractive index } m \text {, in terms of an extinction efficiency } \\
\text { function: } \\
Q=2-\frac{4}{P} \sin P+\frac{4}{P^{2}}(1-\cos P) \text {, } \\
\text { where } P=(4 \pi r / \lambda)(m-1) \text {. } \\
\text { The conditions required for the observation of a purple sun occur at the first maximum } \\
\text { of } Q \text {, around } P=4.1 \text {, where longer (redder) and shorter (bluer) wavelengths of visible } \\
\text { light are extinguished less strongly than intermediate (green) ones; those for a blue sun } \\
\text { occur around } P=5.5 \text {, where longer (redder) wavelengths of visible light are } \\
\text { extinguished more strongly than shorter (bluer) ones; and those for a green sun occur at } \\
\text { the first minimum of } Q \text {, around } P=7.7 \text {, where both longer (redder) and shorter (bluer) } \\
\text { wavelengths of visible light are extinguished more strongly than intermediate (green) } \\
\text { ones (La Mer and Kerker, } 1953 \text {; Ehlers et al., 2014). Assuming a particle refractive } \\
\text { index } m=1.5 \text { and that } \lambda=0.55 \mu \text { is the centre of the visual light spectrum, extinction } \\
\text { efficiency } Q \text { varies between } 1.5 \text { and } 3.2 \text { over this range of parameter } P \text {. }\end{array}$ \\
\hline $\begin{array}{l}\text { Refractive index } \\
(m)\end{array}$ & 1.5 & $\begin{array}{l}\text { The aerosol particle refractive index }(m) \text { typically varies within a range from } 1 \text { to } 2 \text {, } \\
\text { including } m=1.33 \text { (water droplets), } m=1.43-1.46 \text { (volcanogenic sulfate droplets), } \\
m=1.46 \text { (organic oil droplets produced by forest fires) and } m=1.55 \text { (desert sand } \\
\text { particles) (Penndorf, 1953; Yue et al., 1994). }\end{array}$ \\
\hline Radius $(r)$ & $0.5 \mu \mathrm{m}$ & $\begin{array}{l}\text { Assuming a particle refractive index } m=1.5 \text {, the above range of parameter } P \text { from } \\
4.1 \text { to } 7.7 \text { corresponds to a range of aerosol particle radius from } r=0.36 \mu \mathrm{m} \text { (a purple } \\
\text { sun) to } r=0.48 \mu \mathrm{m} \text { (a blue sun) and } r=0.67 \mu \mathrm{m} \text { (a green sun). Non-ideal aerosols } \\
\text { produced by natural sources likewise produce the observation of a purple, blue or green } \\
\text { sun if their size distribution is dominated by particles in this narrow range (Penndorf, } \\
1953 \text {; Horvath et al., 1994), although somewhat broader particle distributions may do } \\
\text { so too (Horvath et al., 1994; Wullenweber et al., 2021). }\end{array}$ \\
\hline Density $(\rho)$ & $1500 \mathrm{~kg} \mathrm{~m}^{-3}$ & $\begin{array}{l}\text { Stothers (1984b) assumes a typical aerosol particle density of approximately } \\
\rho=1500 \mathrm{~kg} \mathrm{~m}^{-3} \text {. }\end{array}$ \\
\hline Optical depth $(\tau)$ & $4.8 \pm 1.2$ & Sect. 3.6 of this paper. \\
\hline Area $(A)$ & $14000000 \mathrm{~km}^{2}$ & Sect. 3.3 of this paper. \\
\hline $\begin{array}{l}\text { Homogeneity } \\
\text { fraction }(f)\end{array}$ & 0.3 & Sect. 3.6 of this paper. \\
\hline
\end{tabular}

\subsection{Aerosol optical depth and mass}

In addition to altering the colour of the sun, the scattering and absorption of sunlight by atmospheric gases and aerosols dims its observed brightness (Bohren and Huffman, 2004). The sun has a visual magnitude $M=-26.74$ (Schaefer, 1993). Adapting Stothers (1984a, b), the optical depth $(\tau)$ of an atmospheric aerosol (at zenith angle $z=0^{\circ}$, i.e. overhead) is related to the reduction in solar magnitude $(\Delta M)$ that it produces at an elevation angle $(\alpha)$ as follows:

$\tau=\frac{\ln 10}{2.5}(\Delta M \sin \alpha-0.2)\left(\alpha>15^{\circ}\right)$, where elevation angle $(\alpha)$ and zenith angle $(z)$ are related as $\alpha=90-z$. Atmospheric refraction can be neglected for $\alpha>15^{\circ}$ (Stothers, 1984b; Schaefer, 1993).

Horvath et al. (1994) report that, due to the physiology of human colour perception, the colour of a blue ${ }^{(+)}$sun remains too bright to be perceived unless its light has been attenuated by a factor of at least $10^{-4}$ and that it is most readily perceived when its light is attenuated by a factor of between $10^{-5}$ and $10^{-6.6}$, equivalent to a reduction in magnitude of between $\Delta M=12.5$ and 16.5. Even if too bright to be perceived as such, a blue ${ }^{(+)}$sun will still be sufficiently reduced in magnitude to be able to be viewed with the naked eye without damage or discomfort at a reduction in magnitude of between, at the very least, about $\Delta M=3.4$ (Stothers, 1984a, 


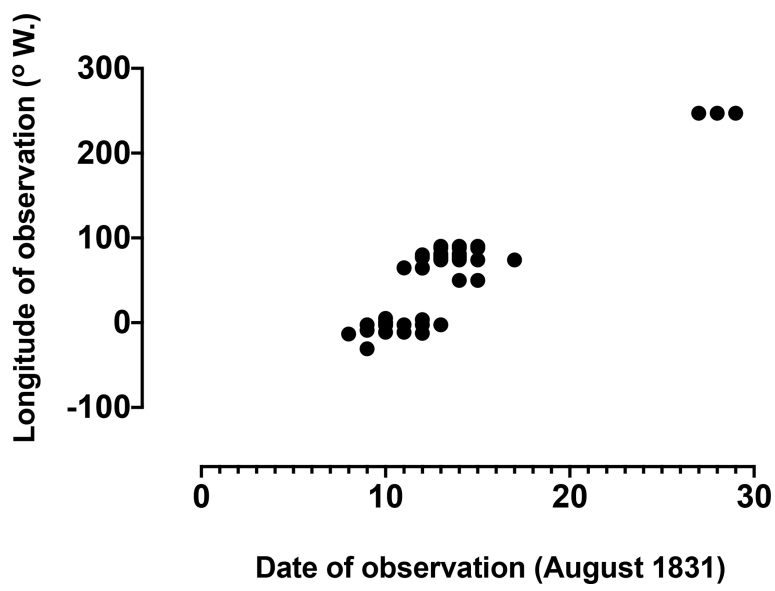

Figure 4. Longitude of blue ${ }^{(+)}$sun observations reported in August 1831 (Appendix A).

b) and, more likely, about $\Delta M=12$ (Schaefer, 1993). At lower reductions in magnitude still, $\Delta M<3.4$, the sun will be more normal in appearance and too bright to observe with the naked eye.

Thus, for suitable aerosol optical depth values $(\tau)$, three observational phases may be distinguished: at higher solar elevations, a sun of normal or near-normal appearance (for $\Delta M<3.4$ and likely for some part of the range from $\Delta M=$ 3.4 to $\Delta M=12$ ); at lower solar elevations, a pale sun able to be viewed with the naked eye (for the remaining part of the range from $\Delta M=3.4$ to $\Delta M=12$ ); and at lower solar elevations still, a blue ${ }^{(+)}$sun able to be viewed with the naked eye (between $\Delta M=12.5$ and $\Delta M=16.5$ ).

These three observational phases are illustrated, for example, in two of the reports reproduced in Table 1 (sources [A10] and [A22]). It is noteworthy that the ratio between the brightness of the typical zenithal sun and a white object diffusely reflecting its light is about $80000: 1$ (Minnaert, 1954). This presumably explains the otherwise paradoxical observation of blue ${ }^{(+)}$sunlight illuminating surfaces and objects when the sun is too bright to be observably blue $^{(+)}$(source [A22]), as the associated attenuation factor of $10^{-4.9}$ is sufficiently close to meet the threshold requirement reported by Horvath et al. (1994).

Nine of the sources (Appendix A) report the local time at which a blue ${ }^{(+)}$sun was observed. The corresponding solar elevation angle $(\alpha)$ can be recovered from this local time, for example, using the National Oceanic and Atmospheric Administration (NOAA) Solar Calculator (available at https: //gml.noaa.gov/grad/solcalc/, last access: 30 May 2021) (Appendix A). Therefore, using this solar elevation angle $(\alpha)$ and the range of reduction in solar magnitude associated with a blue $^{(+)}$sun observation ( $\Delta M=12.5$ to $\Delta M=16.5$ ), Eq. (1) yields a corresponding range of instantaneous aerosol optical depth values $(\tau)$ in each case (Fig. 8).
Five of the sources (Appendix A) report the local time at which the sun was observed with the naked eye after having been observably blue ${ }^{(+)}$in the morning or before becoming observably blue ${ }^{(+)}$in the afternoon. The qualitative descriptions of the appearance of the sun in these latter reports, for example, as a "crystal globe" (source [A8]) or as "moonlike" (source [A10]), suggest the upper end of the $3.4<\Delta M$ $<12$ range in magnitude reduction, i.e. $8<\Delta M<12$. Likewise, recovering solar elevation angle $(\alpha)$ from local time and using this solar elevation angle $(\alpha)$ with the range of reduction in solar magnitude associated with such a naked-eye sun observation ( $\Delta M=8$ to $\Delta M=12$ ), Eq. (1) yields a corresponding range of instantaneous aerosol optical depth values $(\alpha)$ in each case (Fig. 8).

Based on the observations reported in sources [A8]-[A30] between 8 and 17 August 1831, the mean instantaneous optical depth of the aerosol plume is estimated to be $\tau=$ $4.8 \pm 1.2$ (Fig. 8).

Had the aerosol plume produced between 8 and $13 \mathrm{Au}$ gust 1831 been homogenous, however, it would have taken $6 \mathrm{~d}$ to pass over each site and reports of 6 consecutive days of identical blue ${ }^{(+)}$sun observations would have been expected. In fact, the number of consecutive days of blue ${ }^{(+)}$ sun observations varied between 1 and 5 with a mean of about 1.8. Therefore, the aerosol plume cannot have been homogenous. We instead assume that it was sufficiently dense to produce observations of a blue ${ }^{(+)}$sun, with a mean optical depth $\tau=4.8 \pm 1.2$, over only a fraction (approximately $f=1.8 / 6=0.3$ ) of its area. Although the remainder of the aerosol plume was evidently occasionally dense enough to produce ancillary observations of a pale sun (e.g. sources [A9], [A13], [A17] and [A18]), it will be neglected in comparison; taking into account background atmospheric Rayleigh scattering, Wullenweber et al. (2021) determined that in order for an aerosol which is capable of producing observations of a blue ${ }^{(+)}$sun to do so, it must have an optical depth $\tau>0.5$.

Adapting Stothers (1984b, 1996), the mass $M$ of a homogenous atmospheric aerosol over an area $A$ is related to its optical depth $(\tau)\left(\right.$ at $\left.z=0^{\circ}\right)$ as follows:

$M=\frac{4 r \rho}{3 Q} \tau A$,

where the aerosol particles all have radius $r$, density $\rho$ and extinction efficiency $Q$. To account for the inhomogeneity in this case, we treat the area of the aerosol plume over which it was sufficiently dense to produce observations of a blue ${ }^{(+)}$ sun. Using appropriate values for parameters $r, \rho, Q, \tau, A$ and $f$ (Table 2), Eq. (2) yields an aerosol plume mass $M=$ $10.1 \pm 2.5 \times 10^{9} \mathrm{~kg}=10.1 \pm 2.5 \mathrm{Tg}$.

This is a minimum value for the total mass of stratospheric aerosol produced by the source. It does not include the portion of the aerosol plume outside the $30-45^{\circ} \mathrm{N}$ latitude band, which might be approximately estimated to be $15 \%$ (Fig. 2). Further, assuming that the four earlier observa- 


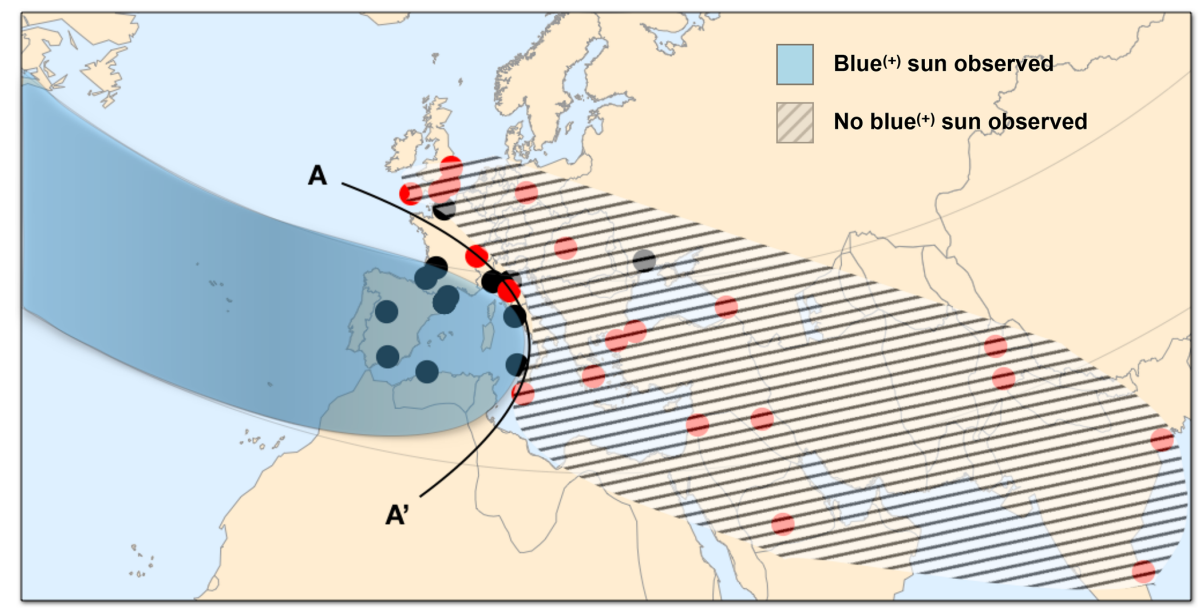

Figure 5. Locations of observations of a blue ${ }^{(+)}$sun (black points) and of null observations (red points) reported in August 1831 (see Appendices A and B). The boundary between the region where a blue ${ }^{(+)}$sun was observed and the region where it was not is delineated approximately by the A-A' curve.

tions of a blue ${ }^{(+)}$sun in the $30-45^{\circ} \mathrm{N}$ latitude band reported from North Africa on 3 August 1831 (source [A1]) and the north-eastern USA on 4 August 1831 (sources [A2]-[A4]) were caused by aerosol produced by the same source, they would be consistent with two smaller bodies of stratospheric aerosol having been produced between 31 July 1831 and 2 August 1831 (sources [A1]-[A3] in Fig. 8).

\subsection{Aerosol source}

The 1831 eruption of Ferdinandea (also known as "Campi Flegrei Mar Sicilia" and "Graham Island") occurred about $50 \mathrm{~km}$ off the south-west coast of Sicily (Gemmellaro, 1831; Washington, 1909; Dean, 1980; Global Volcanism Program, 2013). Starting from a submarine base approximately $150 \mathrm{~m}$ b.s.l. (below sea level), it produced a volcanic island that first rose above sea level around 16 July 1831 and subsequently grew to about $60 \mathrm{~m}$ high and $2 \mathrm{~km}$ in circumference by the time the eruption ceased around 16 August 1831 (Dean, 1980; Spatola et al., 2018). Based on the close coincidence in place ("in the vicinity of Sicily") and date ("between 31 July 1831 and 13 August 1831"), we identify the Ferdinandea eruption as the source of the stratospheric aerosol that was responsible for the blue ${ }^{(+)}$sun observations in August 1831. It is noteworthy that Riccò (1886) made a similar suggestion in the late nineteenth century.

The compositional dynamics of volcanic aerosol plumes can be complex (Mather et al., 2004). However, volcanogenic aerosol in the stratosphere is typically treated as being composed of sulfate droplets containing three-quarters sulfuric acid $\left(\mathrm{H}_{2} \mathrm{SO}_{4}\right)$ and one-quarter water $\left(\mathrm{H}_{2} \mathrm{O}\right)$ (Zielinski, 1995; Toohey and Sigl, 2017). Therefore, in order to produce a minimum $10.1 \pm 2.5 \mathrm{Tg}$ of stratospheric sulfate aerosol, the sulfur yield of the Ferdinandea eruption could not have been less than about $2.5 \pm 0.6 \mathrm{Tg}$.

\section{Discussion}

\subsection{The plausibility of the Ferdinandea eruption as the aerosol source}

The Ferdinandea eruption is described as a small phreatomagmatic ("surtseyan") eruption (Self et al., 1989). The remnant cone today lies underwater and has a volume of about $0.06 \mathrm{~km}^{3}$ (Spatola et al., 2018). The eruption has been assigned a VEI of 3, which is associated with a total volume of erupted tephra of the order of $0.1 \mathrm{~km}^{3}$ (Global Volcanism Program, 2013). Tephra typically has a density of about $10^{12} \mathrm{~kg} \mathrm{~km}^{-3}$ (Crosweller et al., 2012). In order to estimate a sulfur yield for this eruption from these parameters, the typical ocean island basalt affinity for the Sicily Straits Rift Zone (White et al., 2020) is assumed, as is the pre-eruptive melt sulfur content of $3000 \mathrm{ppm}$ reported from Etna by Spilliaert et al. (2006), which marks the very upper end of the concentration range for this volcanic environment (Oppenheimer et al., 2011). These values yield a maximum sulfur yield of $0.3 \mathrm{Tg}$, which is about an order of magnitude smaller than our estimated minimum sulfur yield.

We hypothesize (hypothesis "H1") that the release of the additional sulfur was the result of magma interacting with layers of sulfur-rich sedimentary deposits recently identified at the site of the Ferdinandea eruption (Spatola et al., 2018). These include Messinian evaporites (Spatola et al., 2018). Evaporitic sequences are typically associated with gypsum $\left(\mathrm{CaSO}_{4} \cdot 2 \mathrm{H}_{2} \mathrm{O}\right)$, anhydrite $\left(\mathrm{CaSO}_{4}\right)$ and halite $(\mathrm{NaCl})$. The 1982 eruption of El Chichón, in Mexico, injected about $3.8 \mathrm{Tg}$ of sulfur into the stratosphere (Krueger et al., 2008), as much as 2 orders of magnitude more than would have been expected on the basis of the volume and type of magma erupted alone (Luhr, 1984; Devine et al., 1984; Oppenheimer et al., 2011). The two possible sources for the additional sul- 

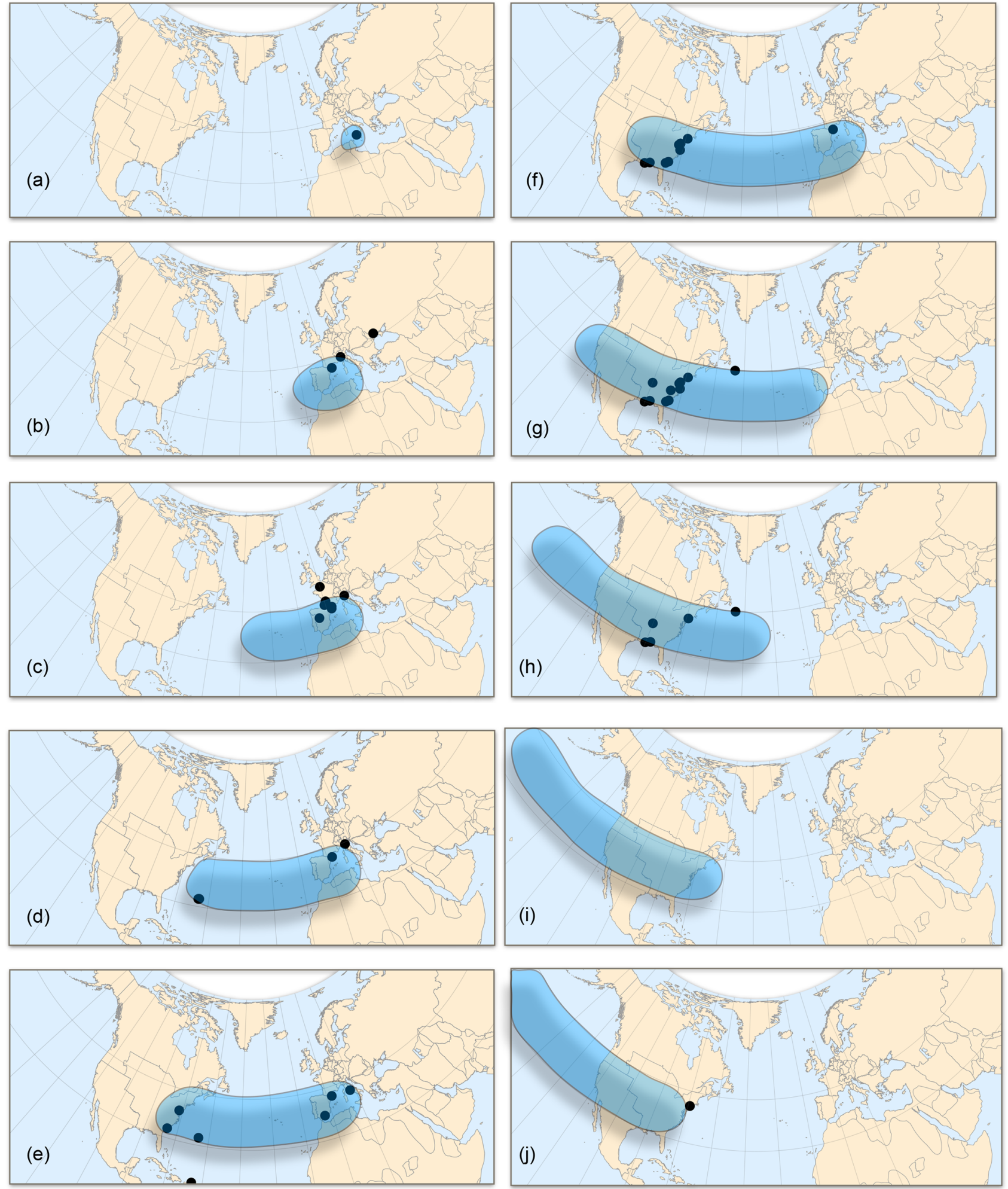

Figure 6. (a-j) Approximate reconstruction of the generation and transport of the aerosol plume responsible for the blue ${ }^{(+)}$sun observations in August 1831. The sequence of observations runs day by day from 8 August (a) to 12 August (e) and from 13 August (f) to 17 August (j). The more minor portion of the aerosol plume which lies outside the $30-45^{\circ} \mathrm{N}$ latitude band is not shown. 


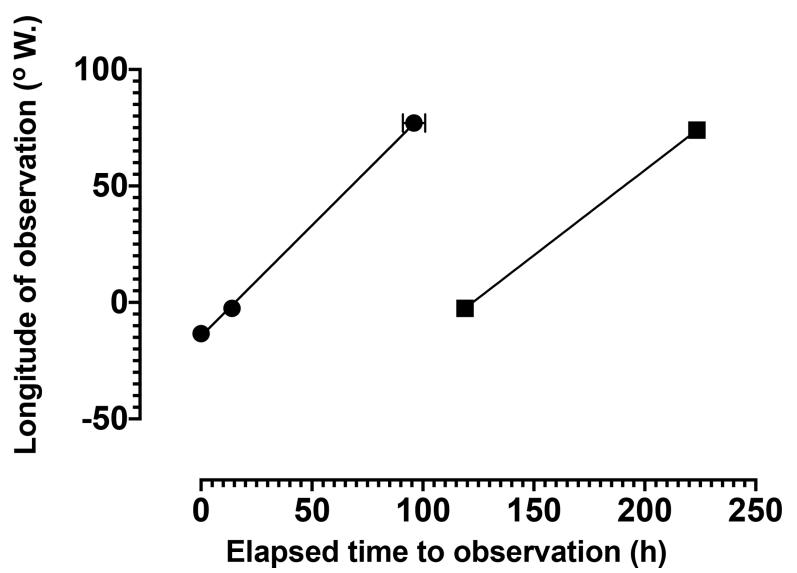

Figure 7. Rate of westward transport of the leading (left) and trailing (right) edges of the aerosol plume, based on sources [A5], [A6], [A17] and [A18] (left) and sources [A6] and [A30] (right). Elapsed time is measured in hours from 18:00 LT (local time, UTC +1) in Sicily on 8 August 1831 (source [A5]).

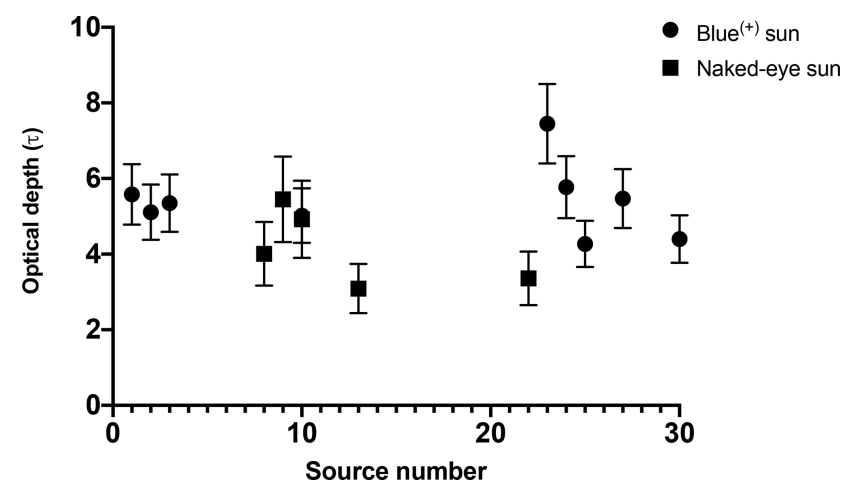

Figure 8. Estimated instantaneous aerosol optical depth ranges. Those marked with a circle represent ranges derived from observations of a blue ${ }^{(+)}$sun, whereas those marked with a square represent ranges derived from observations of a naked-eye sun (either after having been observably blue ${ }^{(+)}$in the morning or before becoming observably blue ${ }^{(+)}$in the afternoon) (see Sect. 3.6).

fur have been identified as an evaporitic anhydrite-bearing sedimentary layer at the site of the El Chichón eruption and deeper subducted sulfide deposits (Rampino and Self, 1984; Duffield et al., 1984; Luhr, 2008). In the case of the Ferdinandea eruption, however, other sulfur-rich components may be relevant too. In some Sicilian Messinian evaporite contexts where hydrocarbons are present, sulfate-reducing microbial activity has resulted in conversion of the gypsum or anhydrite to more easily mobilizable hydrogen sulfide and native sulfur (Ziegenbalg et al., 2010). A hydrocarbon signature has been detected in gas emissions from an active fumarole field about $1 \mathrm{~km}$ from the submerged Ferdinandea cone, although concentrations of sulfur species were not determined (Coltelli et al., 2016).
This hypothesis (H1) is supported by eye-witness observations. During the eruption in July and August 1831, a very strong and unpleasant smell described as a "stink" of sulfur ("una puzza di zolfo") or of sulfur and bitumen ("una puzza di zolfo e di bitume") was reported in towns along or near the south-west coast of Sicily (Gemmellaro, 1831; Russo Ferrugia, 1831). The distance at which it was reported peaked at $100 \mathrm{~km}$ on 11 August 1831 (Russo Ferrugia, 1831), i.e. during the generation of the reconstructed stratospheric aerosol plume between 8 and 13 August 1831. Silver objects became tarnished at the same time (Gemmellaro, 1831; Russo Ferrugia, 1831), suggesting that sufficiently high atmospheric concentrations of hydrogen sulfide (and water vapour) reacted with the silver to form a blackened ("tarnished") surface layer of silver sulfide (Inaba, 1996).

A VEI of 3 is associated with "possible" stratospheric injection rather than the "definite" stratospheric injection associated with a VEI of 4 (Newhall and Self, 1982; Global Volcanism Program, 2013). We hypothesize (hypothesis "H2") that injection of the volcanic aerosol into the stratosphere by the Ferdinandea eruption was supported by favourable meteorological conditions. The 2018 eruption of Anak Krakatau, an island volcano on the rim of the Krakatau volcano, in Indonesia, was similar in style and magnitude to that of Ferdinandea (Table 3; Fig. 9a, b). It is likewise assigned a VEI of 3 (Global Volcanism Program, 2013). Crucially, sustained phreatomagmatic activity during the eruption produced a column with an updraught in which the vertical velocity was enhanced by convective instability (Prata et al., 2020). Thus, for 6 continuous days, a plume of positively buoyant aerosol was able to reach an altitude which varied between 16 and $18 \mathrm{~km}$ a.s.l. (above sea level), at times above the local tropopause at $16.8 \pm 0.8 \mathrm{~km}$ (Prata et al., 2020).

Anticyclones with subsiding air typically inhibit deep convection in high summer in the central Mediterranean region, even though large amounts of convective instability may be present in the mid-troposphere above an inversion (Taszarek et al., 2018). The mean height of the tropopause over the south-eastern Mediterranean in the summer is approximately $14 \mathrm{~km}$ (Retalis and Cartalis, 1997). We hypothesize (H2) that phreatomagmatic activity during the Ferdinandea eruption was sufficiently sustained, at times, to produce a column with updraughts enhanced by environmental convective instability above any inversion, such that positively buoyant aerosol was able to breach the tropopause, similar to the Anak Krakatau eruption.

This hypothesis (H2) is also supported by eye-witness observations. Approaching the site of the eruption on 5 August 1831 , i.e. just prior to the generation of the reconstructed stratospheric aerosol plume between 8 and 13 August 1831, Smythe (1831) reported from a distance of $55 \mathrm{~km}$ that: “... a stupendous column of white steam was observed, rising majestically far above the western horizon, splendidly illumined (sic) by the setting sun...". At that time, on $6 \mathrm{Au}-$ gust 1831, continuous episodes of violent "cypress-tree-like" 
Table 3. Comparison of the eruptions of Ferdinandea and Anak Krakatau. References: Dean (1980), Retalis and Cartalis (1997), Global Volcanism Project (2013), Spatola et al. (2018), Gouthier and Paris (2019), and Prata et al. (2020).

\begin{tabular}{|c|c|c|}
\hline Eruption & $\begin{array}{l}\text { Ferdinandea } \\
\text { ("Campi Flegrei Mar Sicilia" and "Graham Island") }\end{array}$ & Anak Krakatau \\
\hline Location & $\begin{array}{l}\text { In the Straits of Sicily, } 50 \mathrm{~km} \text { off the south-west coast } \\
\text { of Sicily, Italy }\left(37.1^{\circ} \mathrm{N}, 12.7^{\circ} \mathrm{E}\right)\end{array}$ & $\begin{array}{l}\text { At sea level in the caldera of the Krakatau volcano, in } \\
\text { Indonesia }\left(6.1^{\circ} \mathrm{S}, 105.4^{\circ} \mathrm{E}\right)\end{array}$ \\
\hline Date & $\begin{array}{l}\text { Around } 16 \text { July to } 16 \text { August } 1831 \text { (with a prior sub- } \\
\text { marine phase from around June to } 16 \text { July } 1831 \text { ) }\end{array}$ & 22 December 2018 to 6 January 2019 \\
\hline $\begin{array}{l}\text { Predominant } \\
\text { eruption style }\end{array}$ & Surtseyan (phreatomagmatic) & Surtseyan (phreatomagmatic) \\
\hline Erupted volume & $0.06-0.1 \mathrm{~km}^{3}$ & $0.045 \mathrm{~km}^{3}$ \\
\hline VEI & 3 & 3 \\
\hline $\begin{array}{l}\text { Altitude of local } \\
\text { tropopause }\end{array}$ & Approximately 14 km a.s.l. & $16.8 \pm 0.8 \mathrm{~km}$ a.s. 1 \\
\hline Max. column height & $\begin{array}{l}\text { Above the local tropopause } \\
\text { (see Sect. } 3.5 \text { of this paper) }\end{array}$ & $18 \mathrm{~km}$ \\
\hline
\end{tabular}

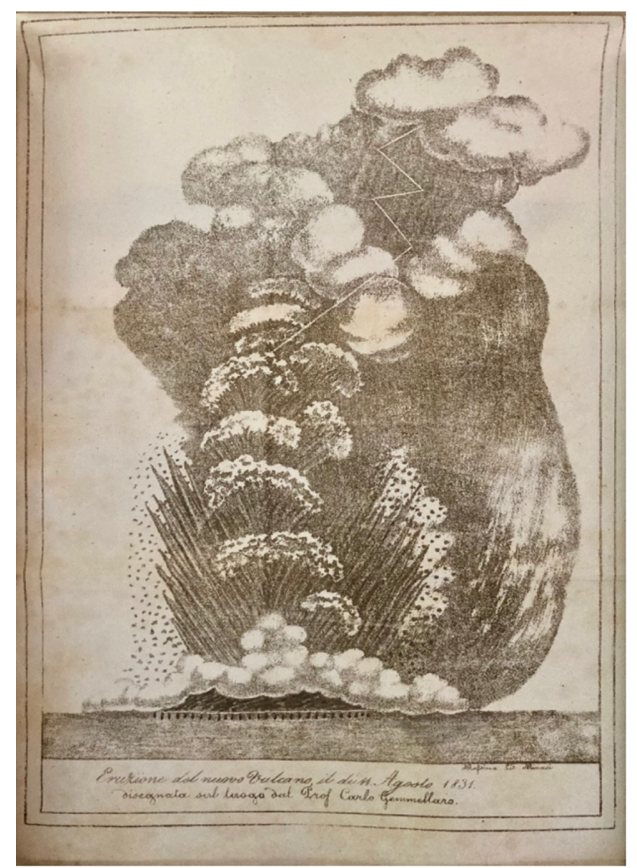

(a)

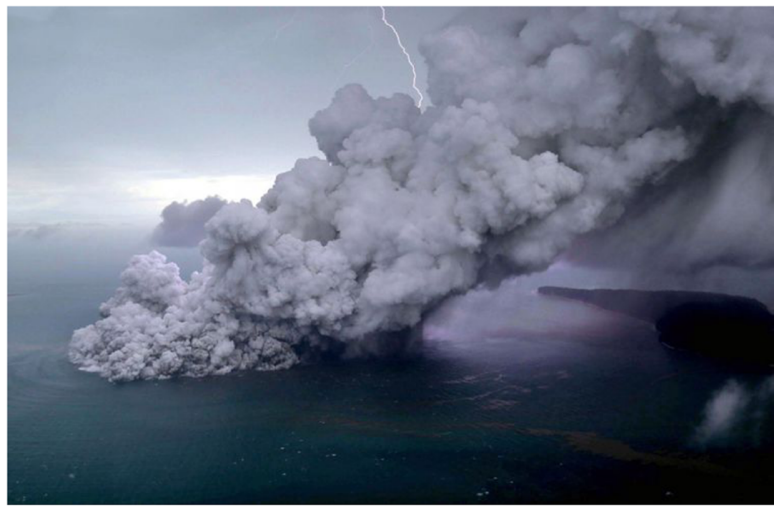

(b)

Figure 9. (a). Sea-level sketch of the Ferdinandea eruption on 11 August 1831 drawn by Gemmellaro (1831). Characteristic features of phreatomagmatic activity are portrayed: pyroclastic material is being explosively ejected in successive cypress-tree- or cock's-tail-like forms at the base of a rising column of steam and ash (Francis and Oppenheimer, 2004); a "base surge" is visible. The column appears to be sheared downwind from the observer. A volcanic lightning discharge in the upper part of the eruption column is visible. (b) Photograph of the Anak Krakatau eruption taken from a light aircraft on 23 December 2018. (Image reproduced with permission: Nurul Hidayat/Antara Foto Agency/Reuters.) Characteristic features of phreatomagmatic activity are again visible (Francis and Oppenheimer, 2004) including a "base surge". The column is inclined up and to the right of the observer. A volcanic lightning discharge is again visible. 
phreatomagmatic explosions were separated by quiescent periods of 2-3 h (Smythe, 1831). By 11 August 1831, however, phreatomagmatic activity had significantly intensified: Gemmellaro (1831) reported that the continuous episodes lasted between 30 and $45 \mathrm{~min}$ (Fig. 9) and were separated by quiescent periods of only 2-3 min. Stratospheric injection may also have been achieved earlier in the eruption, even if it did not lead to the formation of an aerosol with the parameters necessary to produce observations of a blue ${ }^{(+)}$sun. On 22 July 1831, the eruption column reportedly subtended an angle of at least $20^{\circ}$ at a distance of $50 \mathrm{~km}$ from the site of the eruption, suggesting that the (visible) column was at least $18 \mathrm{~km}$ high (Hoffmann, 1831; Symons et al., 1888).

Profiles of temperature, humidity and winds in the atmospheric column in the central Mediterranean in late July and early August 1831 will be required to test the hypothesis (H2) that environmental convective instability increased the height of the eruption column, permitting aerosol injection above the tropopause. Although no observations comparable to modern radiosonde ascents exist for this period, a proxy is provided by the recent extension of global atmospheric reanalysis datasets to the early nineteenth century, for example, the Twentieth Century Reanalysis (20CR) versions 2 and 3 (Compo et al., 2011; Slivinski et al., 2019).

Zonal mean wind fields derived from twentieth century data suggest that easterly wind velocity $\left(40^{\circ} \mathrm{N}\right.$, July) would not be expected to exceed about $10 \mathrm{~ms}^{-1}$ below an altitude of approximately $20 \mathrm{~km}(30 \mathrm{hPa})$ in the low stratosphere and that a velocity of about $20 \mathrm{~ms}^{-1}$ would only be expected to be reached at an altitude of approximately $35 \mathrm{~km}(8 \mathrm{hPa})$ in the mid-stratosphere (Randel, 2003). A particular focus for this hypothesis testing will therefore examine whether the aerosol is likely to have reached only the low stratosphere, in which case the easterly aerosol transport velocity estimated in Sect. $3.4\left(20 \mathrm{~ms}^{-1}\right)$ would be inconsistent with the easterly wind velocity suggested for the lower stratosphere by the zonal mean wind field data $\left(10 \mathrm{~ms}^{-1}\right)$ by a factor of 2 , or whether it could have reached the mid-stratosphere.

A reanalysis-based reconstruction of atmospheric circulation will also permit investigation of whether aerosol transport in different wind directions from the eruption site at different altitudes was responsible for the only blue ${ }^{(+)}$sun observation otherwise unaccounted for, which reportedly occurred on 9 August 1831 in Odessa, Ukraine (source [A7]; Fig. 5), as well as ancillary reports of unusual haze or fog elsewhere in the Mediterranean or Europe (e.g. sources [A1], [A5], [B8], [B13] and [B15]).

\subsection{Comparison with independent datasets}

Assuming that the sulfate aerosol plume was transported in the stratosphere, it could have been expected to produce occasional observations of a fiery twilight glow from 8 August 1831 onward. Such twilight glows are often referred to as "volcanic sunsets" and are characteristic of volcanogenic sul- fate aerosols in the stratosphere (Meinel and Meinel, 1991). The stratospheric altitude is sufficiently high for the sulfate aerosol to continue to scatter ("reflect") sunlight, so long as it is not blocked by tropospheric clouds, even when the sun is well below the horizon (Symons et al., 1888; Meinel and Meinel, 1991). Thus, stratospheric aerosol to the east of an observer may produce the observation of a twilight glow before dawn, whereas stratospheric aerosol to the west may produce the observation of a twilight glow after sunset.

Consistent with this expectation, nine of the sources that report observations of a blue ${ }^{(+)}$sun between 8 and 17 August 1831 also report observations of a fiery twilight glow whose locations move from east to west in conjunction with the sites of the blue ${ }^{(+)}$sun observations (Appendix A). In addition, a longer sequence of twilight glow observations was reported at Palermo between August and October 1831 (source [A5]). The sequence appears to have a periodicity of about $18 \mathrm{~d}$. This suggests that, although the stratospheric aerosol plume only maintained the parameters necessary to produce observations of a blue ${ }^{(+)}$sun over about three-quarters of one circuit of Earth (path A-B-C-D in Fig. 10), it nevertheless remained dense enough thereafter to continue to produce observations of a twilight glow over two further circuits of Earth (path A-B-C-D-A in Fig. 10 and Fig. 11). A periodicity of $18 \mathrm{~d}$ is equivalent to a transport rate of $20^{\circ}$ (long.) $\mathrm{d}^{-1}$ or about $0.84^{\circ}$ (long.) $\mathrm{h}^{-1}$, very close to the aerosol plume transport rate $\left(0.85^{\circ}\right.$ (long.) $\left.\mathrm{h}^{-1}\right)$ estimated in Sect. 3.4 on the basis of the blue ${ }^{(+)}$sun observations.

Six of the null observation sources also report observations of a twilight glow in August 1831 (Appendix B), appearing to reflect the initial transport of the stratospheric aerosol plume or the two smaller precursory bodies of stratospheric aerosol (e.g. sources [B12], [B13] and [B14]) and/or the return of the aerosol plume after a first (e.g. sources [B5] and [B14]) or second circuit (e.g. source [B16]) of Earth.

As the stratospheric sulfate aerosol plume continued to be transported, it would have dispersed to form a more homogenous stratospheric sulfate aerosol. Assuming that sulfate aerosol typically has a stratospheric residence time with an $e$-folding timescale (i.e. the time taken to decline by a value $e^{-1}=0.37$ ) of about 1 year (Robock, 2000), approximately $63 \%$ of it would have returned to the troposphere after 1 year and $86 \%$ after 2 years. Under the premise that the earliest possible sulfate deposition on the Greenland ice sheet from the Ferdinandea eruption could have taken place via a direct tropospheric route from July or August 1831 and that significant deposition via the stratospheric route could continue for no more than 2 years (Robock, 2000), it would be expected that an increase in sulfate deposition would be detected in Greenland ice cores between July or August 1831 and around August 1833. The magnitude of the expected increase should correspond to our estimated minimum sulfur yield for the Ferdinandea eruption of about $2.5 \pm 0.6 \mathrm{Tg}$.

Consistent with this expectation, Sigl et al. (2013) report a peak in sulfate deposition in a Greenland ice core between 


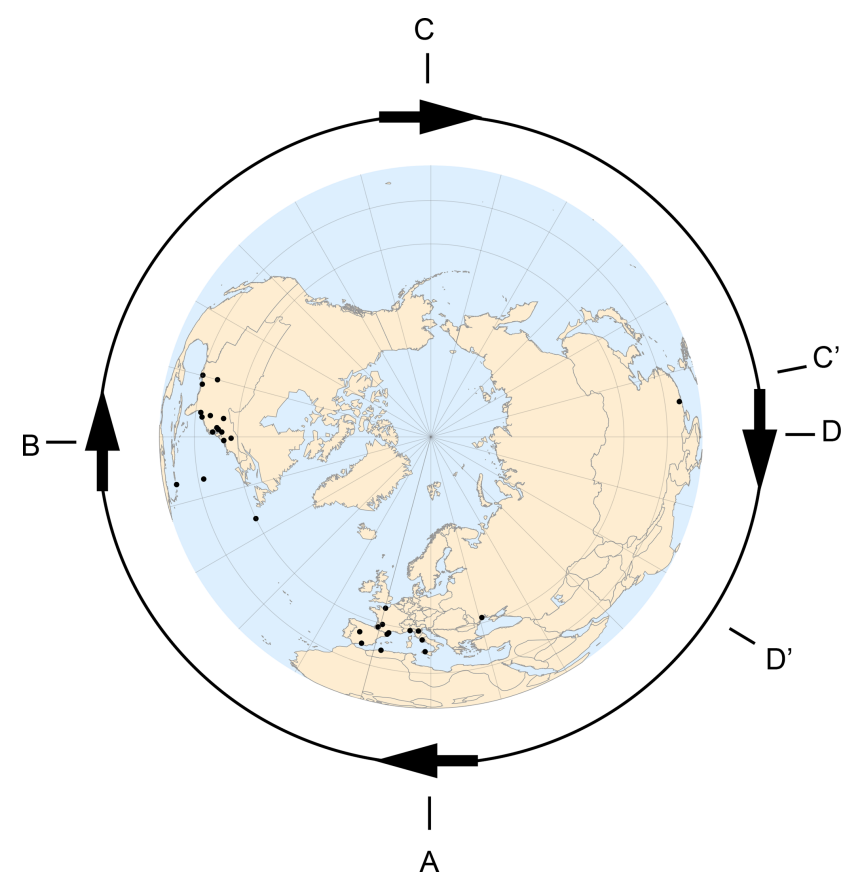

Figure 10. Aerosol transport path A-B-C-D-A around Earth in 1831. The locations of the blue ${ }^{(+)}$sun observations reported in August 1831 (Appendix A) are shown. The last reported observation of a blue ${ }^{(+)}$sun occurred around 28 August 1831 in China (source [A31]) near point C', whereas the first observations where no blue ${ }^{(+)}$sun was reported occurred in India and Pakistan (sources [B1]-[B4]) near point D'.

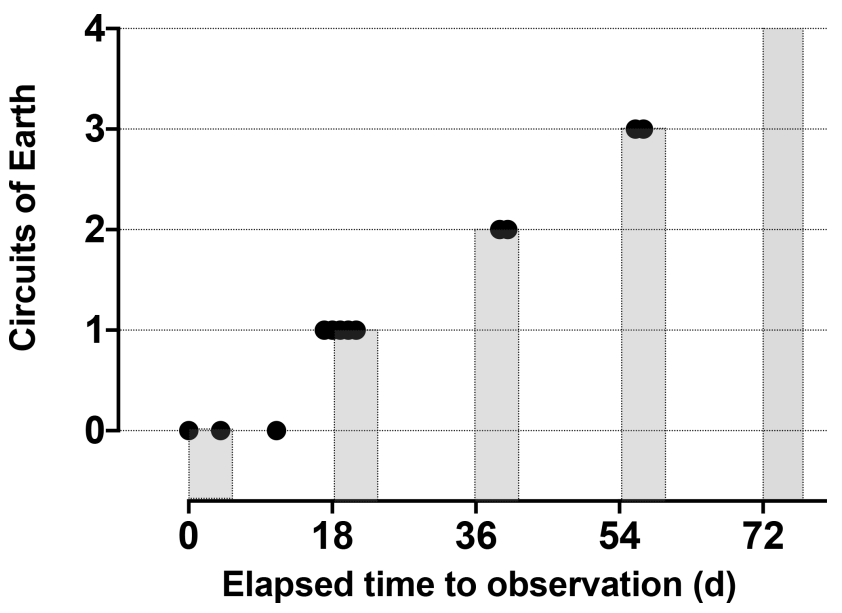

Figure 11. Twilight glow observations reported in Palermo, Sicily, Italy, between August and October 1831 (source [A5]). Elapsed time is calculated in days from the twilight glow observation on 8 August 1831 (source [A5]). The periodicity of the observations is consistent with the aerosol responsible completing one circuit of Earth around transport path A-B-C-D-A (Fig. 10) in approximately $18 \mathrm{~d}$.

$1831.4 \pm 0.25$ and $1833.7 \pm 0.25$. Assuming a source eruption of Babuyan Claro, in the Philippines, Toohey and Sigl (2017) estimate that the sulfur yield of the eruption responsible for the peak was $12.98 \pm 3.41 \mathrm{Tg}$. However, if the source eruption had been located at a mid- or high-latitude site, instead of a low-latitude site, this estimate could be reduced by as much as $60 \%$ (Toohey and Sigl, 2017). Presuming a source eruption at an unidentified site in the Northern Hemisphere (and using a different set of Greenland ice cores), Gao et al. (2008) estimate the sulfur yield of the eruption responsible for the peak to have been lower at about $4.2 \mathrm{Tg}$. Thus, our estimated minimum sulfur yield for the Ferdinandea eruption already represents about $60 \%$ of the total eruption sulfur yield estimated by Gao et al. (2008).

Based on this close coincidence in the expected and actual sulfate deposition profile (and although more minor contributions from other sources cannot be ruled out), we identify the Ferdinandea eruption as the source of the climate forcing stratospheric sulfate aerosol in 1831.

\section{Conclusions}

One of the largest climate forcing volcanic eruptions of the nineteenth century took place in 1831 (Zielinski, 1995; Gao et al., 2008; Arfeuille et al., 2014; Toohey and Sigl, 2017). Here, we have used a newly compiled dataset of reported observations of a blue, purple and green sun in August 1831 to reconstruct the transport of a stratospheric aerosol plume from that eruption. Thus, we are able to constrain the location of the eruption to a mid-latitude site between 30 and $45^{\circ} \mathrm{N}$. Those prior estimates of the mass of stratospheric sulfate aerosol responsible for the 1831 Greenland ice core sulfate deposition peaks which assumed a source eruption at a low-latitude site will, therefore, have been overstated (Zielinski, 1995; Arfeuille et al., 2014; Toohey and Sigl, 2017). For a given mass of stratospheric sulfate aerosol, Toohey et al. (2019) recently demonstrated that eruptions at midor high-latitudes can produce stronger hemispheric climate forcing than low-latitude eruptions.

Using additional reports where a blue, purple or green sun was not recorded, despite active observation, we are also able to constrain the longitude of the eruption and, hence, are able to identify it as the eruption of Ferdinandea, which took place about $50 \mathrm{~km}$ off the south-west coast of Sicily $\left(37.1^{\circ} \mathrm{N}, 12.7^{\circ} \mathrm{E}\right)$ in July and August 1831 . The eruption is assigned a VEI of 3 (Global Volcanism Program, 2013). Its modest magnitude has commonly caused it to be discounted or overlooked when identifying the likely source of the stratospheric sulfate aerosol in 1831 (Camuffo and Enzi, 1995; Zielinski, 1995; Robinson et al., 2001, Arfeuille et al., 2014; Toohey and Sigl, 2017). However, we argue here that the Ferdinandea eruption must be considered in the context of its geological and meteorological environment, rather than in isolation. We hypothesize (H1) that despite its modest magnitude, its magmatic system was nevertheless sufficient to trigger the release of sulfur from sedimentary deposits at 
the site of the eruption and (H2) that convective instability in the troposphere contributed to aerosol reaching the stratosphere, such that the Ferdinandea eruption did indeed result in the production of the stratospheric sulfate aerosol in 1831.

Our reconstruction of the transport of the stratospheric aerosol plume can be tested and improved upon with a search for further sources reporting the observation of a blue, purple or green sun in 1831. Our two hypotheses $(\mathrm{H} 1, \mathrm{H} 2)$ as to the Ferdinandea eruption can be tested through further study of its magmatic system and geological context as well as with a reanalysis-based reconstruction of atmospheric circulation in July and August 1831. If we are correct, one of the largest climate forcing volcanic eruptions of the nineteenth century would effectively have been hiding in plain sight. This would arguably "lower the bar" for the types of eruptions capable of having a substantial climate forcing impact. This example serves as a useful reminder that VEI values were not intended to be reliably correlated with eruption sulfur yields unless supplemented with compositional analyses (Newhall and Self, 1982).

Analysis of reported observations of unusual atmospheric optical phenomena both in 1831 and in 1883 may support further investigation in a number of additional directions.

For example, the first observation of a blue ${ }^{(+)}$sun in the equivalent connected sequence following the onset of the most explosive phase of the 1883 Krakatau eruption occurred of the order of $1 \mathrm{~d}$ later (Symons et al., 1888). This suggests the rapid formation of a stratospheric aerosol whose size distribution is dominated by particles with a radius of the order of $0.5 \mu \mathrm{m}$ (Table 2). The close coincidence between the substantial increase in the intensity of phreatomagmatic activity during the Ferdinandea eruption between 6 and 11 August 1831 and the first observation of a blue ${ }^{(+)}$sun in the connected sequence on 8 August 1831 (Sect. 4.1) suggests that a similarly rapid stratospheric aerosol formation occurred in that case too. Given that, for example, the stratospheric aerosol produced by the 1991 Pinatubo eruption took several months to grow to a typical size between 0.3 and $0.5 \mu \mathrm{m}$ (Self et al., 1993), it would be interesting to consider the nature of the atypical microphysical processes that could be involved in these two rare cases.

Further, the durations of reported twilight glow observations in 1883 were used to constrain the altitude of the aerosol responsible (Symons et al., 1888; Meinel and Meinel, 1991). In the context of testing hypothesis H2, an analysis of the duration of the reported twilight glow observations mentioned in Sect. 4.2 as well as an analysis of a supplementary collected body of contemporary observations of twilight glows (and other unusual twilight phenomena) should provide independent evidence as to the altitude reached by the aerosol responsible in 1831 .

Thus, the examples of 1831 and 1883 again underline that eye-witness accounts of historical geophysical events should not be neglected as a source of valuable scientific data (Guidoboni, 2010; Pyle and Barclay, 2020). The further be- fore the nineteenth century an event took place, the more difficult it is likely to be to be able to collect primary sources reporting any associated observations of a blue, purple or green sun, or of other unusual atmospheric optical phenomena such as twilight glows. Nevertheless, where an adequate collection of primary sources can be collated, it can likewise be expected to be helpful in terms of, for example, reconstructing the circulatory state of the stratosphere (Hamilton and Sakazaki, 2018) or constraining the latitude, longitude and date of the source event which produced the aerosol responsible and the altitude at which it was present (Symons et al., 1888). 


\section{Appendix A}

Table A1. Observations of a blue, green or purple sun in August 1831.

\begin{tabular}{|c|c|c|c|c|c|c|}
\hline $\begin{array}{l}\text { Source } \\
\text { no. }\end{array}$ & $\begin{array}{l}\text { Lat. } \\
\left({ }^{\circ} \mathrm{N}\right)\end{array}$ & $\begin{array}{l}\text { Long. } \\
\left({ }^{\circ} \mathrm{E}\right)\end{array}$ & $\begin{array}{l}\text { Time } \\
\text { zone } \\
\text { (UTC) }\end{array}$ & Brief description of source & $\begin{array}{l}\text { Solar } \\
\text { elevation } \\
\left({ }^{\circ}\right)\end{array}$ & $\begin{array}{l}\text { Elapsed } \\
\text { time } \\
\text { (h) }\end{array}$ \\
\hline A1 & $\begin{array}{l}36.7 \\
\text { (est.) }\end{array}$ & $\begin{array}{l}1.8 \\
\text { (est.) }\end{array}$ & +1 & $\begin{array}{l}\text { Whilst sailing off the coast of Algeria from Oran to Algiers the French } \\
\text { military engineer Antoine Rozet observed a "clear blue" naked-eye sun } \\
\text { (with a sunspot) through a "very remarkable" fog between 07:00 and } \\
07: 15 \text { LT on } 3 \text { August (Rozet, 1833). He also reported that this fog had } \\
\text { appeared at intervals all along the North African coast between } 15 \text { July } \\
\text { and } 15 \text { August and that, at Oran, he had seen a naked-eye sun through } \\
\text { the fog on several occasions for several minutes at a time (Rozet, 1833). } \\
\text { Note that the Dordogne left Oran on } 1 \text { August and arrived at Algiers on } \\
4 \text { August (Rozet, 1832). }\end{array}$ & $\begin{array}{l}25.6 \\
(07: 15 \mathrm{LT})\end{array}$ & \\
\hline A2 & 42.9 & -74.6 & -5 & $\begin{array}{l}\text { A meteorological register taken at Canajoharie (New York State, USA) } \\
\text { relates the observation of a "pale violet" naked-eye sun at 17:00 LT on } \\
4 \text { August (Hough, 1855). }\end{array}$ & 23.3 & \\
\hline A3 & $\begin{array}{l}40.0 \\
\text { (est.) }\end{array}$ & $\begin{array}{l}-76.3 \\
\text { (est.) }\end{array}$ & -5 & $\begin{array}{l}\text { A traveller on the Susquehanna River (Pennsylvania, USA) related the } \\
\text { observation of a "violet" naked-eye sun through a thin cloud } \\
\text { "overspreading the sky" at 17:00 LT on } 4 \text { August to the editors of the } \\
\text { Lancaster Miscellany (Hazard's Register, 1831). }\end{array}$ & 24.5 & \\
\hline A4 & 40.4 & -80.0 & -5 & $\begin{array}{l}\text { A report from Pittsburgh (Pennsylvania, USA), reproduced in the New } \\
\text { York Evening Post (1831a), relates the observation of sunlight whose } \\
\text { colour "resembled that of the lilach (sic) flowers" on } 4 \text { August. The } \\
\text { article also relates the observation of unusual twilight phenomena from } \\
\text { the first week of August (New York Evening Post, 1831a). }\end{array}$ & & \\
\hline A5 & 38.1 & 13.4 & +1 & $\begin{array}{l}\text { Niccolò Cacciatore, the Italian astronomer and director of the Palermo } \\
\text { Observatory (Sicily, Italy), observed a "pale whitish-blue" sun through } \\
\text { a "dense" fog at 18:00 LT on } 8 \text { August (Cacciatore, } 1831 \mathrm{~b} \text { ). The full } \\
\text { text of this report is reproduced in Table } 1 \text {. He also reported the } \\
\text { observation of dense fogs between } 23 \text { and } 26 \text { July and } 5 \text { and } 8 \text { August } \\
\text { as well as twilight glows on } 4,6,8,12 \text { and } 19 \text { August and between } 25 \\
\text { and } 29 \text { August, } 17 \text { and } 18 \text { September, and } 4 \text { and } 5 \text { October (Cacciatore, } \\
\text { 1831a, b, c, d). }\end{array}$ & & 0 \\
\hline A6 & 42.2 & 2.5 & +1 & $\begin{array}{l}\text { The Catalan naturalist Francesc Bolòs recorded } 5 \text { or } 6 \mathrm{~d} \text { of observations } \\
\text { of unusually coloured and dimmed suns at Olot (Garrotxa, Catalonia, } \\
\text { Spain): on } 9 \text { and } 10 \text { August, the sun appeared "white", "silvery", } \\
\text { "shimmering" and "moon-like" from its rise until 08:00 LT, when it } \\
\text { began to produce weak sunlight with a "purplish" colour, remaining in } \\
\text { this state for the remainder of the day; the appearance of the sun on } 11 \\
\text { and } 12 \text { August was much the same, although it appeared to be briefly } \\
\text { "red" before it became "white" and began to shine earlier at } 07: 00 \text { LT } \\
\text { and a little less weakly than the previous } 2 \mathrm{~d} \text {; on } 13 \text { August, the sun } \\
\text { rose with a "blue" colour (and a sunspot) beginning to shine with a } \\
\text { "blueish" colour at } 07: 00 \text { LT and remaining like this until 17:00 LT } \\
\text { when it dimmed again such that at } 18: 30 \text { LT it looked "white" and } \\
\text { "moon-like"; the sun was brighter on } 14 \text { August and was restored to } \\
\text { its normal appearance on } 15 \text { August (Bolòs, 1831). Bolòs (1831) also } \\
\text { reported the observation of a twilight glow between } 9 \text { and 10 } \\
\text { August } 1831 \text {. }\end{array}$ & & $\begin{array}{l}14 \\
(08: 00 \text { LT }) \\
119 \\
(17: 00 \text { LT })\end{array}$ \\
\hline
\end{tabular}

“est." denotes estimated. 
Table A1. Continued.

\begin{tabular}{|c|c|c|c|c|c|c|}
\hline $\begin{array}{l}\text { Source } \\
\text { no. }\end{array}$ & $\begin{array}{l}\text { Lat. } \\
\left({ }^{\circ} \mathrm{N}\right)\end{array}$ & $\begin{array}{l}\text { Long. } \\
\left({ }^{\circ} \mathrm{E}\right)\end{array}$ & $\begin{array}{l}\text { Time } \\
\text { zone } \\
\text { (UTC) }\end{array}$ & Brief description of source & $\begin{array}{l}\text { Solar } \\
\text { elevation } \\
\left({ }^{\circ}\right)\end{array}$ & $\begin{array}{l}\text { Elapsed } \\
\text { time } \\
(\mathrm{h})\end{array}$ \\
\hline A7 & 46.5 & 30.7 & +2 & $\begin{array}{l}\text { A report from Odessa (Ukraine), reproduced in the German newspaper } \\
\text { Augsburger Ordinari Postzeitung (1831), relates the observation of an } \\
\text { "almost violet" naked-eye sun (with a sunspot) through an "almost } \\
\text { invisible" fog through the whole afternoon on } 9 \text { August. The article also } \\
\text { relates the observation of unusual twilight phenomena in the first week } \\
\text { of August (Augsburger Ordinari Postzeitung, 1831). }\end{array}$ & & \\
\hline A8 & 44.4 & 8.9 & +1 & $\begin{array}{l}\text { A report in the Italian newspaper Gazzetta di Genova (1831) relates that } \\
\text { the sun appeared at Genoa (Liguria, Italy) through a "thin layer of } \\
\text { vapour" as a naked-eye "crystal globe" (with a sunspot) at 17:00 LT on } \\
9 \text { August, before turning "pale red" and then "violet" in colour. }\end{array}$ & 27.1 & \\
\hline A9 & $\begin{array}{l}40.6 \\
\text { (est.) }\end{array}$ & $\begin{array}{l}-5.0 \\
\text { (est.) }\end{array}$ & +1 & $\begin{array}{l}\text { A meteorological report from Ávila Province (Castile and Léon, Spain) } \\
\text { in the Spanish newspaper El Correo (1831) relates that at about } \\
\text { 17:00 LT on } 9 \text { August, the sun was observed to become as "pale and } \\
\text { white as the moon" and that on } 10 \text { August, the sun continued to be pale } \\
\text { but with a "bluish" and subsequently "whitish" colour. } \\
\text { Note that a report from Madrid (Castile and Léon, Spain) dated } 18 \\
\text { August, reproduced in the German newspaper Allgemeine Zeitung } \\
\text { München (1831a), also relates that an unusual appearance of the sun } \\
\text { had recently been observed for several days, with a colour varying } \\
\text { between "blue", "red" and "white". }\end{array}$ & 37.7 & \\
\hline A10 & 43.8 & -0.6 & +1 & $\begin{array}{l}\text { A letter from the French naturalist Léon Dufour was read out on } 22 \\
\text { August at the meeting of the Académie des Sciences relating the } \\
\text { observation of a "white moon-like" naked-eye sun at Saint-Sever } \\
\text { (Nouvelle-Aquitaine, France) at 17:00 LT which turned "pale blue" at } \\
\text { 18:00 LT (Dufour, 1831). The full text of this report is reproduced in } \\
\text { Table 1. }\end{array}$ & $\begin{array}{l}33.7 \\
(17: 00 \mathrm{LT}) \\
22.9 \\
(18: 00 \mathrm{LT})\end{array}$ & \\
\hline A11 & $\begin{array}{l}44.8(\mathrm{~B}) \\
42.7(\mathrm{P})\end{array}$ & $\begin{array}{l}0.6(\mathrm{~B}) \\
2.9(\mathrm{P})\end{array}$ & +1 & $\begin{array}{l}\text { The French scientist François Arago informed the } 22 \text { August meeting } \\
\text { of the Académie des Sciences that, on the basis of letters he had received } \\
\text { from Bordeaux (B) and Perpignan (P), the same phenomenon observed } \\
\text { at Saint-Sever (source [A10]) was observed throughout southern France } \\
\text { (Arago, 1831). }\end{array}$ & & \\
\hline A12 & 49.5 & 0.1 & +1 & $\begin{array}{l}\text { The French scientist François Arago informed the } 29 \text { August meeting } \\
\text { of the Académie des Sciences that the same phenomenon observed at } \\
\text { Saint-Sever (source [A10]) had also been seen at Le Havre (Seine- } \\
\text { Maritime, France) by M. Mathieu on } 10 \text { August (Mathieu, 1831). } \\
\text { Note that, at the same meeting of the Académie des Sciences, the } \\
\text { French naturalist François Désiré Roulin related that it had also been } \\
\text { seen to the east as far as Bologna (Emilia-Romagna, Italy), where it } \\
\text { lasted for several days (Roulin, 1831). }\end{array}$ & & \\
\hline
\end{tabular}

“est." denotes estimated. 
Table A1. Continued.

\begin{tabular}{|c|c|c|c|c|c|c|}
\hline $\begin{array}{l}\text { Source } \\
\text { no. }\end{array}$ & $\begin{array}{l}\text { Lat. } \\
\left({ }^{\circ} \mathrm{N}\right)\end{array}$ & $\begin{array}{l}\text { Long. } \\
\left({ }^{\circ} \mathrm{E}\right)\end{array}$ & $\begin{array}{l}\text { Time } \\
\text { zone } \\
\text { (UTC) }\end{array}$ & Brief description of source & $\begin{array}{l}\text { Solar } \\
\text { elevation } \\
\left({ }^{\circ}\right)\end{array}$ & $\begin{array}{l}\text { Elapsed } \\
\text { time } \\
\text { (h) }\end{array}$ \\
\hline A13 & 41.9 & 12.5 & +1 & $\begin{array}{l}\text { The future Roman Catholic archbishop Vicenzo Tizzani recorded } \\
\text { several days of observations of unusually coloured and dimmed suns } \\
\text { at Rome (Lazio, Italy) between } 9 \text { and } 16 \text { August: a thick fog covering } \\
\text { the sky about 17:20 LT ("ore } 22 \text { " - a locally defined time of } 22 \mathrm{~h} \text { after } \\
\text { sunset the previous day) on the } 9 \text { August caused a "veiled moon-like" } \\
\text { naked-eye sun to be seen; the appearance of the sun was the same on } \\
10 \text { August; on } 12 \text { August, from about } 17: 16 \text { LT ("ore } 22 \text { ") onwards, a } \\
\text { naked-eye sun was variously seen through a dense fog to be "turquoise", } \\
\text { "ashy","yellowish" and "rosy" in colour; and a "rosy" naked-eye sun } \\
\text { was seen at sunset on } 16 \text { August (Tizzani and Croce, } 2015 \text { ). He also } \\
\text { reported the observation of a twilight glow on } 3,9,10 \text { and } 12 \\
\text { August (Tizzani and Croce, 2015). Note that a system of time-keeping } \\
\text { in widespread use in (especially southern) Italy at the time reckoned } \\
\text { the } 24 \text { h period to start at sunset, requiring the resetting of clocks and } \\
\text { watches according to almanacs of changing sunset times (Laurent, } \\
\text { 1821). Sunset on 9 August took place at 19:20 LT and on } 12 \text { August } \\
\text { at 19:16 LT (National Oceanic and Atmospheric Administration } \\
\text { (NOAA) Solar Calculator: https://gml.noaa.gov/grad/solcalc/, last } \\
\text { access: } 30 \text { May 2021). }\end{array}$ & $\begin{array}{l}20.8 \\
(17: 20 \text { LT }) \\
20.9 \\
(17: 16 \text { LT })\end{array}$ & \\
\hline A14 & 37.2 & -3.6 & +1 & $\begin{array}{l}\text { A letter from Sr. Estrella (1831) to the Spanish newspaper El Correo } \\
\text { relates the observation, at Granada (Andalucia, Spain), of a "blue" sun } \\
\text { through a "thin cloud along the horizon" by the "tarce" (sic) on } 12 \\
\text { August. He also relates the observation of twilight glows there on } 10 \text {, } \\
11,12 \text { and } 13 \text { August (Estrella 1831). }\end{array}$ & & \\
\hline A15 & 32.3 & -64.8 & -4 & $\begin{array}{l}\text { Sir David Brewster read a letter from Augustus Harvey, a doctor in } \\
\text { Bermuda, before the 10th meeting of the British Association for the } \\
\text { Advancement of Science, relating his memory of observation of "blue" } \\
\text { or "bluish" sunlight there on } 11 \text { and } 12 \text { August (Harvey, 1839). }\end{array}$ & & \\
\hline A16 & 32.3 & -64.5 & -4 & $\begin{array}{l}\text { Sir David Brewster read a letter from lieutenant colonel William Reid, } \\
\text { governor of Bermuda, before the 10th meeting of the British } \\
\text { Association for the Advancement of Science, relating that the present } \\
\text { collector of customs in Bermuda had been on board a boat } 15 \text { miles } \\
\text { (approx. } 24 \mathrm{~km} \text { ) east of the island on } 11 \text { August and had noticed that the } \\
\text { sun was of a "light green" or "bluish green" colour (Reid, 1839). }\end{array}$ & & \\
\hline A17 & 32.7 & -80.0 & -5 & $\begin{array}{l}\text { An article in the Charleston Courier (South Carolina, USA), } \\
\text { reproduced in the Savannah Republican (1831, p.2), relates the obser- } \\
\text { vation of } 5 \mathrm{~d} \text { of unusually coloured and dimmed suns: on } 11 \text { August, } \\
\text { the sun was "pale" and "feeble" throughout the day; on } 12 \text { August, the } \\
\text { sun was the same but with the addition of a "slight bluish tinge"; on } 13 \\
\text { August, the sun was the same, if less pronounced; on } 14 \text { August, the } \\
\text { sunlight at noon was a "very sensible blue" colour and as dim as during } \\
\text { the recent eclipse (12 February), whereas the sun was a "pale green- } \\
\text { blue" and could be observed with the naked eye at a few minutes before } \\
\text { 18:00 LT; and on the evening of } 15 \text { August, the sun had still not } \\
\text { recovered "his usual splendour". The article also relates the observation } \\
\text { of a twilight glow on } 12 \text { August } 1831 \text { (Savannah Republican, 1831). }\end{array}$ & & $\begin{array}{l}96 \pm 5 \\
(12 \mathrm{Aug})\end{array}$ \\
\hline
\end{tabular}


Table A1. Continued.

\begin{tabular}{|c|c|c|c|c|c|c|}
\hline $\begin{array}{l}\text { Source } \\
\text { no. }\end{array}$ & $\begin{array}{l}\text { Lat. } \\
\left({ }^{\circ} \mathrm{N}\right)\end{array}$ & $\begin{array}{l}\text { Long. } \\
\left({ }^{\circ} \mathrm{E}\right)\end{array}$ & $\begin{array}{l}\text { Time } \\
\text { zone } \\
\text { (UTC) }\end{array}$ & Brief description of source & $\begin{array}{l}\text { Solar } \\
\text { elevation } \\
\left({ }^{\circ}\right)\end{array}$ & $\begin{array}{l}\text { Elapsed } \\
\text { time } \\
\text { (h) }\end{array}$ \\
\hline A18 & 38.8 & -77.0 & -5 & $\begin{array}{l}\text { A meteorological register taken at the Alexandria Museum (Alexandria, } \\
\text { Virginia, USA), reproduced in the Alexandria Gazette (1831a) which } \\
\text { relates the observation of } 5 \mathrm{~d} \text { of unusually coloured and dimmed suns: } \\
\text { on } 11 \text { August, the sun had a pale and "silver-like" appearance; between } \\
12 \text { August and } 14 \text { August, the sun was alternately "white", "brassy", } \\
\text { "green" and "blue" (with a naked-eye sunspot); and it began resuming } \\
\text { its normal appearance on } 15 \text { August. The notes also relate the observa- } \\
\text { tion of a twilight glow as the sun set "each day" at the same time that } \\
\text { resembled the "light of a great fire" (Alexandria Gazette 1831a). }\end{array}$ & & $\begin{array}{l}96 \pm 5 \\
(12 \mathrm{Aug})\end{array}$ \\
\hline A19 & 18.7 & -64.3 & -4 & $\begin{array}{l}\text { Whilst surveying around the island of Anegada (British Virgin Islands), } \\
\text { the British explorer Sir Robert Schomburgk observed the overcast sky } \\
\text { to be a "threatening" dark bluish colour on } 12 \text { August } \\
\text { (Schomburgk, 1848). }\end{array}$ & & \\
\hline A 20 & 30.0 & -90.1 & -6 & $\begin{array}{l}\text { A report from New Orleans (Louisiana, USA) in the local French } \\
\text { language newspaper L'Abeille (1831, p.1) relates that, between } 12 \text { or } \\
13 \text { and } 15 \text { August, the sun was observed to set in a "suspended sea" } \\
\text { which dimmed its light and made it a "blue", "indigo-blue" or } \\
\text { "greenish" colour. }\end{array}$ & & \\
\hline A21 & 38.3 & -77.5 & -5 & $\begin{array}{l}\text { An article in the Fredericksburg Arena (Virginia, USA), reproduced } \\
\text { in the Alexandria Gazette (1831b), relates the observation of a pale blue } \\
\text { sun (with a naked-eye sunspot) on the evening of } 13 \text { and the morning of } \\
14 \text { August. }\end{array}$ & & \\
\hline A22 & 36.9 & -76.3 & -5 & $\begin{array}{l}\text { A report from Norfolk (Virginia, USA), reproduced in the } \\
\text { Washington National Intelligencer (1831), relates the observation of a } \\
\text { variously "lively green", "cerulean", "silver white" and "pale yellow" } \\
\text { sun (with a naked-eye sunspot) on } 13 \text { and } 14 \text { August. At 17:00 LT on } \\
13 \text { August, it appeared like a "a globe of silver through the thick haze } \\
\text { which overspread the Heavens, shorn of its beams". The full text of this } \\
\text { report is reproduced in Table 1. The report also relates a twilight glow } \\
\text { on } 13 \text { August (Washington National Intelligencer 1831). }\end{array}$ & 22.7 & \\
\hline A23 & 38.8 & -77.0 & -5 & $\begin{array}{l}\text { A letter from the American amateur scientist Benjamin Hallowell } \\
\text { (1831) to the Washington National Intelligencer relates that, at about } \\
\text { midday on } 13 \text { August in Alexandria (Virginia, USA), he observed that } \\
\text { the sun shining through a "body of vapor suspended in the heavens" had } \\
\text { a "silvery" appearance, changing between } 15: 00 \text { LT and 16:00 LT to a } \\
\text { "greenish-blue" and that it descended "below the body of vapor" about } \\
15-20 \text { min before sunset; he noted the presence of a naked-eye sunspot. } \\
\text { He also reported a twilight glow on } 12 \text { August (Hallowell, 1831). } \\
\text { Note that Breen (2005) reproduces a similar account from a letter writ- } \\
\text { ten by Emma Mordecai who relates the observation of a blue sun at } \\
\text { about 16:00 LT on } 13 \text { August nearby in Richmond (Virginia, USA). }\end{array}$ & $\begin{array}{l}34.9 \\
(16: 00 \mathrm{LT})\end{array}$ & \\
\hline
\end{tabular}


Table A1. Continued.

\begin{tabular}{|c|c|c|c|c|c|c|}
\hline $\begin{array}{l}\text { Source } \\
\text { no. }\end{array}$ & $\begin{array}{l}\text { Lat. } \\
\left({ }^{\circ} \mathrm{N}\right)\end{array}$ & $\begin{array}{l}\text { Long. } \\
\left({ }^{\circ} \mathrm{E}\right)\end{array}$ & $\begin{array}{l}\text { Time } \\
\text { zone } \\
\text { (UTC) }\end{array}$ & Brief description of source & $\begin{array}{l}\text { Solar } \\
\text { elevation } \\
\left({ }^{\circ}\right)\end{array}$ & $\begin{array}{l}\text { Elapsed } \\
\text { time } \\
\text { (h) }\end{array}$ \\
\hline A24 & 32.1 & -81.1 & -5 & $\begin{array}{l}\text { A report in the Savannah Georgian (Georgia, USA), reproduced in the } \\
\text { Georgia Messenger (1831), relates that on } 13 \text { August a "blue" naked- } \\
\text { eye sun was seen from 17:00 LT until sunset and that, although less dim, } \\
\text { a "blue" sun (with a sunspot) continued to be seen on } 14 \text { August. }\end{array}$ & 26.5 & \\
\hline $\mathrm{A} 25$ & 30.7 & -88.0 & -6 & $\begin{array}{l}\text { A report reproduced from the Mobile Register (Alabama, USA) } \\
\text { (1831) relates that a variously "pale blue", "violet" or "sea-green", } \\
\text { naked-eye sun (with a sunspot) was seen from 17:00 LT until 18:00 LT } \\
\text { on } 13 \text { August, a "bluish" sun was seen on the morning of } 14 \text { August and } \\
\text { a "pale green" sun was seen at 06:00 LT on the morning of } 15 \text { August } \\
\text { (Mobile Register, 1831). }\end{array}$ & $\begin{array}{l}19.5 \\
(17: 00 \mathrm{LT})\end{array}$ & $\begin{array}{l}126 \\
(18: 00 \mathrm{LT})\end{array}$ \\
\hline A26 & 40.7 & -74.0 & -5 & $\begin{array}{l}\text { A report published in the New York Evening Post (New York State, } \\
\text { USA) on } 16 \text { August relates the observation of a sun for "several days } \\
\text { past" (i.e. likely between } 13 \text { and } 15 \text { August) which on rising was "dull } \\
\text { white, slightly tinged with green" and which, between } 30 \text { and } 45 \text { min } \\
\text { later, was brighter but with sunlight of a "faint silvery hue, somewhat } \\
\text { greenish, not unlike the color of the silk of green corn" (New York } \\
\text { Evening Post, 1831b, p. 2). The report also relates the observation of } \\
\text { a twilight glow (New York Evening Post, 1831b). }\end{array}$ & & \\
\hline A27 & $\begin{array}{l}45.0 \\
\text { (est.) }\end{array}$ & $\begin{array}{l}-50.0 \\
\text { (est.) }\end{array}$ & $\begin{array}{l}-3 \\
\text { or } \\
-4\end{array}$ & $\begin{array}{l}\text { Whilst sailing across the north Atlantic from New York to Liverpool, } \\
\text { the American clergyman Calvin Colton observed } 2 \text { or } 3 \mathrm{~d} \text { of an } \\
\text { unusually coloured and dimmed sun: on } 14 \text { August, a "dark purple" } \\
\text { naked-eye sun (with a sunspot) was seen at around 17:00 LT (although } \\
\text { a member of the ship's crew indicated that the phenomenon had begun } \\
\text { around 15:00 LT with the "unusual symptoms" gradually increasing); } \\
\text { on } 15 \text { August, the appearance of the sun was the same, although even } \\
\text { darker in the afternoon; and it was "not till the third or fourth day that } \\
\text { the heavens began to wear their natural appearances" (Colton, 1835). } \\
\text { Note that the Silas Richards left New York on } 9 \text { August and arrived at } \\
\text { Liverpool on } 28 \text { August; Colton believed that the ship was "on the } \\
\text { Banks of Newfoundland, or in the neighbourhood" when the } \\
\text { observations took place (Colton, 1835). }\end{array}$ & $\begin{array}{l}25.1 \\
(17: 00 \mathrm{LT})\end{array}$ & \\
\hline A28 & 35.7 & -80.5 & -5 & $\begin{array}{l}\text { A report in the Western Carolinian (Salisbury, North Carolina, USA) } \\
\text { relates the observation of a "blue" naked-eye sun (with a sunspot) on } \\
14 \text { August; the report further relates that "some of the old inhabitants of } \\
\text { this place say that it presented the same appearance in } 1816 \text { or } 1817 \text { " } \\
\text { (Western Carolinian, 1831). }\end{array}$ & & \\
\hline A29 & 36.0 & -90.0 & -6 & $\begin{array}{l}\text { A handwritten note inscribed in a family Bible by Margaret Hess } \\
\text { relates that she observed the sun to have a "clear blue culler (sic)" in } \\
\text { Trenton (Tennessee, USA) on the afternoon of } 14 \text { and the morning of } \\
15 \text { August (Hess, 1831). }\end{array}$ & & \\
\hline A30 & 40.7 & -74.0 & -5 & $\begin{array}{l}\text { A report in the New York Commercial Advertiser (New York State, } \\
\text { USA), reproduced in the London Morning Post (1831), relates that a } \\
\text { naked-eye sun which was "green, as the sea water or Brazilian emerald" } \\
\text { was observed between 17:00 LT and 19:30 LT on } 17 \text { August. }\end{array}$ & $\begin{array}{l}20.1 \\
(17: 00 \mathrm{LT})\end{array}$ & $\begin{array}{l}223.5 \\
(19: 30 \mathrm{LT})\end{array}$ \\
\hline A31 & 23.1 & 113.3 & +8 & $\begin{array}{l}\text { A report in the English language Canton Register newspaper } \\
\text { (Guangzhou, China) relates the observation of two parhelia "here" on } \\
4 \text { September as well as the observation, "about a week previously" and } \\
\text { "for several days" (i.e. likely between } 27 \text { and } 29 \text { August), of a pale green } \\
\text { sun on both rising and setting (Canton Register, 1831). }\end{array}$ & & \\
\hline
\end{tabular}

“est." denotes estimated. 


\section{Appendix B}

Table B1. Null Observations.

\begin{tabular}{|c|c|c|c|}
\hline $\begin{array}{l}\text { Source } \\
\text { no. }\end{array}$ & $\begin{array}{l}\text { Lat. } \\
\left({ }^{\circ} \mathrm{N}\right)\end{array}$ & $\begin{array}{l}\text { Long. } \\
\left({ }^{\circ} \mathrm{E}\right)\end{array}$ & Brief description of source \\
\hline B1 & $\begin{array}{l}22.0 \\
\text { (est.) }\end{array}$ & $\begin{array}{l}88.0 \\
\text { (est.) }\end{array}$ & $\begin{array}{l}\text { The Repulse, an Honourable East India Company vessel, was at anchor at the entrance to the Hooghly } \\
\text { River (now Bhāgirathi-Hooghly River), West Bengal, India, from } 5 \text { June until } 8 \text { August 1831, before } \\
\text { sailing to Penang, Malaysia, and reaching Singapore by } 28 \text { August (Bayliffe and Rawes, 2016). } \\
\text { Whilst recording daily weather conditions, no observations of unusual atmospheric optical } \\
\text { phenomena (UAOP) were reported in the logbook in July or August. }\end{array}$ \\
\hline B2 & 13.1 & 80.3 & $\begin{array}{l}\text { Astronomical observations were recorded at the Honourable East India Company Observatory at } \\
\text { Madras (now Chennai), India, in } 1831 \text { (Taylor, 1832). No episodes of unusual stellar dimming were } \\
\text { reported. No equivalent meteorological observation book can be found. }\end{array}$ \\
\hline B3 & $\begin{array}{l}34.0 \\
\text { (est.) }\end{array}$ & $\begin{array}{l}75.0 \\
\text { (est.) }\end{array}$ & $\begin{array}{l}\text { The French naturalist Victor Jacquemont was travelling in "Cashmere" (now Jammu and Kashmir, } \\
\text { India) between } 8 \text { May and } 19 \text { September } 1831 \text { (Jacquemont, 1834). He reported no UAOP in July } \\
\text { nor August. }\end{array}$ \\
\hline B4 & 31.5 & 74.3 & $\begin{array}{l}\text { The British explorer Sir Alexander Burnes was resident in Lahore, Pakistan, between } 18 \text { June and } \\
16 \text { August before travelling onward to reach Simla (now Shimla), India, in September } 1831 \text { (Burnes, } \\
\text { 1834). He reported no UAOP in July nor August. }\end{array}$ \\
\hline B5 & $\begin{array}{l}25.0 \\
\text { (est.) }\end{array}$ & $\begin{array}{l}45.0 \\
\text { (est.) }\end{array}$ & $\begin{array}{l}\text { A record of historical events (Enwan Al-Majed fi Tarekh Najd) in Najd Province, Saudi Arabia, } \\
\text { reports unusual twilight phenomena during the first and second week of August } 1831 \text { and a twilight } \\
\text { glow in the evening of } 23 \text { August (Basurah, 2010). Two less precisely dated observations of a twilight } \\
\text { glow are also related, one lasting } 3 \mathrm{~d} \text { (between 1831 and 1832) and another which lasted some } \\
\text { months (between } 1832 \text { and 1833) (Basurah, 2010). }\end{array}$ \\
\hline B6 & 33.3 & 44.4 & $\begin{array}{l}\text { An English Protestant missionary, Anthony Groves, kept a day-to-day journal of his residency in } \\
\text { Baghdad, Iraq, in } 1830 \text { and } 1831 \text { (Groves, 1832). He reported no UAOP in July nor August. }\end{array}$ \\
\hline B7 & 42.3 & 41.7 & $\begin{array}{l}\text { The Swiss naturalist and antiquarian Frédéric Du Bois de Montpéreux, travelled in the Caucasus } \\
\text { between } 1831 \text { and } 1834 \text {. Despite, for example, recording weather observations in Redoute-Kalé } \\
\text { (now Kulevi, Georgia) on 2, } 3 \text { and } 4 \text { August 1831, he reported no UAOP in July nor August (Du } \\
\text { Bois de Montpéreux, 1839). }\end{array}$ \\
\hline B8 & 33.5 & 36.3 & $\begin{array}{l}\text { The head of the Lazaristes mission in Damascus (Syria), M. Poussou, reported in a letter to } \\
\text { M. Etienne, procureur général of the Lazaristes congregation, dated } 12 \text { September 1831, that for } \\
\text { "about the last two months" (i.e. likely since about mid-July) the atmosphere there had been "laden } \\
\text { [with vapours]" and the sun had been pale, including appearing as if seen through "crêpe" [fabric] } \\
\text { for at least fifteen minutes after sunrise' (Poussou, 1831). He also reported the observation of } \\
\text { a twilight glow "during this period", both before sunrise and after sunset, although he does not say } \\
\text { whether continuously or occasionally and, if the latter, on which dates (Poussou, 1831). }\end{array}$ \\
\hline B9 & 41.0 & 29.0 & $\begin{array}{l}\text { Gustavus Richard Brown Horner, surgeon aboard the American vessel, the John Adams, arrived } \\
\text { at Constantinople (now Istanbul, Turkey) on } 10 \text { August } 1831 \text { (Horner, 1831). The John Adams had } \\
\text { arrived off the Dardanelles (now Çanakkale Boğazı, in Turkey) on } 4 \text { August (see source [B10]). He } \\
\text { kept a day-to-day record of the weather. With the exception of an "atmosphere loaded with vapours } \\
\text { impenetrable to the sun" on } 22 \text { August, he mentioned no UAOP in July nor August (Horner, 1831). }\end{array}$ \\
\hline
\end{tabular}

"est." denotes estimated. 
Table B2. Continued.

\begin{tabular}{|c|c|c|c|}
\hline $\begin{array}{l}\text { Source } \\
\text { no. }\end{array}$ & $\begin{array}{l}\text { Lat. } \\
\left({ }^{\circ} \mathrm{N}\right)\end{array}$ & $\begin{array}{l}\text { Long. } \\
\left({ }^{\circ} \mathrm{E}\right)\end{array}$ & Brief description of source \\
\hline B10 & 40.3 & 26.4 & $\begin{array}{l}\text { The American naval officer David Porter arrived off the Dardanelles (now Çanakkale Boğazı, in } \\
\text { Turkey) on } 4 \text { August } 1831 \text { aboard the American vessel the John Adams and reached Constantinople } \\
\text { (now Istanbul, Turkey) by } 10 \text { August (Porter, 1835). The purpose of his visit to Constantinople was } \\
\text { to ratify the first treaty agreed between the USA and the Ottoman Empire. He reported no UAOP in } \\
\text { July nor August, although he did describe a remarkable hail storm which took place in Istanbul on } \\
\text { the same day as the ratification ceremony. }\end{array}$ \\
\hline B11 & 37.5 & 23.4 & $\begin{array}{l}\text { The American zoologist, James DeKay, sailed through the Mediterranean to Turkey in } 1831 . \mathrm{He} \\
\text { gave a close description of an early phase of the eruption of Ferdinandea, off the coast of Sicily, } \\
\text { Italy, as he passed it on the morning of the } 16 \text { July (DeKay, 1833). The vessel reached the island of } \\
\text { Crete, Greece, around } 27 \text { July, and then made its way via Milos, Hydra (around } 30 \text { July), Poros } \\
\text { (a few days before } 13 \text { August), Tinos, Andros, Chios, Lemnos, Tenedos and the Dardanelles (now } \\
\text { Çanakkale Boğazı, in Turkey) to reach Constantinople (now Istanbul, Turkey) later in August } \\
\text { (DeKay, 1833). He reported no UAOP in July nor August, although he did describe a remarkable } \\
\text { hail storm which took place in Istanbul (see source [B10]). }\end{array}$ \\
\hline B12 & 35.9 & 14.4 & $\begin{array}{l}\text { The British doctor (and assistant inspector of army hospitals) John Davy reported the observation } \\
\text { in Malta of a twilight glow for many evenings successively in August } 1831 \text { (Davy, 1832). }\end{array}$ \\
\hline B13 & 43.8 & 11.3 & $\begin{array}{l}\text { An article in the Italian newspaper, the Gazzetta di Firenze (Florence, Tuscany, Italy) (1831) reports } \\
\text { the observation of a dense haze and a twilight glow in the evenings for several days prior to } 13 \\
\text { August. }\end{array}$ \\
\hline B14 & 46.2 & 6.1 & $\begin{array}{l}\text { Referring to the observations of a blue sun made by Léon Dufour in France on } 10 \text { August } 1831 \\
\text { (source [A10]), an article in the Swiss newspaper, the Journal de Genève (Geneva, Switzerland) } \\
\text { (1831) reports the observation of a twilight glow there in the evenings of } 10 \text { and } 30 \text { August. }\end{array}$ \\
\hline B15 & 47.5 & 19.0 & $\begin{array}{l}\text { An article in the German newspaper Allgemeine Zeitung München }(1831 \mathrm{~b}, \mathrm{p} .936) \text { relates that the } \\
\text { air in Budapest, Hungary, was filled with a thin fog on } 11 \text { August } 1831 \text { which dimmed the distant } \\
\text { mountains and "almost made it difficult for anyone to breathe". }\end{array}$ \\
\hline B16 & 51.8 & 12.3 & $\begin{array}{l}\text { The German astronomer Samuel Heinrich Schwabe, whose dedicated solar observations between } \\
1826 \text { and } 1843 \text { led to his discovery of the } 11 \text {-year sunspot cycle, lived in Dessau, Germany. Whilst } \\
\text { reporting all of the most notable astronomical and meteorological phenomena he observed in 1831, } \\
\text { he mentioned a twilight glow that had occurred on } 25,26 \text { and } 27 \text { September (Schwabe, 1831). }\end{array}$ \\
\hline B17 & $\begin{array}{l}50.8(\mathrm{G}) \\
51.5(\mathrm{C}) \\
50.1(\mathrm{P}) \\
53.0(\mathrm{~B})\end{array}$ & $\begin{array}{ll}1.1 & (\mathrm{G}) \\
0.3 & (\mathrm{C}) \\
5.5 & (\mathrm{P}) \\
0.0 & (\mathrm{~B})\end{array}$ & $\begin{array}{l}\text { Meteorological observations across the UK for August } 1831 \text { were reported by "Dr. BURNEY" in } \\
\text { Gosport (G), "Mr. THOMPSON" in Chiswick, London (C), "Mr. GIDDY" in Penzance (P) and } \\
\text { "Mr. VEALL" in Boston (B), all in England, UK (Philosophical Magazine 1831). No UAOP were } \\
\text { reported in the accompanying day-to-day comments. }\end{array}$ \\
\hline
\end{tabular}


Data availability. All of the data necessary to repeat our analyses are found in the tables in this paper.

Author contributions. CG carried out the analysis presented in this study and drafted the paper. CK and SE provided guidance and expertise on the volcanological and geological contexts and critically reviewed the paper. DS provided guidance and expertise on the meteorological context (including proposing the pertinence of the convective instability mechanism) and critically reviewed the paper.

Competing interests. The contact author has declared that neither they nor their co-authors have any competing interests.

Disclaimer. Publisher's note: Copernicus Publications remains neutral with regard to jurisdictional claims in published maps and institutional affiliations.

Special issue statement. This article is part of the special issue "Interdisciplinary studies of volcanic impacts on climate and society". It is not associated with a conference.

Acknowledgements. The authors would like to thank James Lequeux (Observatoire de Paris) for undertaking a search of the papers of François Arago at the Observatoire de Paris; Donatella Randazzo (Osservatorio Astronomico di Palermo) for assistance with a search of the archives of the Osservatorio Astronomico di Palermo; Marc Prohom Duran (Servei Meteorològic de Catalunya) for providing an extract from Quintana i Mari (1938) reproducing the observations of Francesc Bolòs (source [A6]); Julia Rodriguez Sanchez (University College London) for assistance with translation of materials from Catalan; Sabine Rodda for assistance with the translation of materials from German; Kai Deng (University College London) and Zheyu Tian (University College London) for assistance with translation of materials from Mandarin; Colin Graham (Gide Loyrette Nouel) for assistance with translation and historiographical interpretation of materials from Mandarin; Alessandro Aiuppa (Università degli Studi di Palermo), Attilio Sulli (Università degli Studi di Palermo), Sergio Calabrese (Università degli Studi di Palermo) and Walter D'Alessandro (Università degli Studi di Palermo) for valuable discussions regarding the geological context of the 1831 Ferdinandea eruption; and Michael Sigl (Universität Bern) for valuable discussions regarding sulfate deposition peaks in Greenland ice cores in 1831. The authors would also like to thank Fred Prata and two anonymous reviewers for the improvements to the paper which resulted from their comments. Christopher Garrison is also grateful for an E.A. Milne Travelling Fellowship grant from the Royal Astronomical Society (Burlington House, Piccadilly, London, W1J 0BQ, UK) to support a research visit to Sicily in 2018 .
Review statement. This paper was edited by Francis Ludlow and reviewed by Fred Prata and two anonymous referees.

\section{References}

Alexandria Gazette: "Meteorological Observations Taken at the Alexandria Museum, Aug. 1831, Friday, 2 September", p. 1, 1831a.

Alexandria Gazette: "The sun on Saturday evening...", Thursday, 18 August, p.1, 1831 b.

Allgemeine Zeitung München: "Spanien, Madrid, 18 Aug...", Samstag, 3 September, No. 246, p. 981, 1831a.

Allgemeine Zeitung München: "Pesth, 12 Aug...", Montag, 22 August, No. 234, p. 936, 1831 b.

Arago, F.: Communication to the 22 August 1831 meeting of the Académie des Sciences, in: Journal de Chimie Médicale, de Pharmacie et de Toxicologie, Tome VII, Chez Béchet Jeune, Paris, 1831.

Arago, F.: Notices scientifiques par M. Arago: Des Comètes en général, et en particulier, de la Comète qui doit reparaître en 1832 et dont la révolution est de 6 ans 3/4, in: Bureau des Longitudes Annuaire pour l'An 1832, Bachelier Père et Fils, Paris, 1832.

Arfeuille, F., Weisenstein, D., Mack, H., Rozanov, E., Peter, T., and Brönnimann, S.: Volcanic forcing for climate modeling: a new microphysics-based data set covering years 1600present, Clim. Past, 10, 359-375, https://doi.org/10.5194/cp-10359-2014, 2014.

Augsburger Ordinari Postzeitung: "Odessa, den 12 August, Im hiesigen Courrier liest man Folgendes...”, Sonntag, 4 September, No. 243, 1831.

Barry, R. G. and Hall-McKim, E. A.: Essentials of the Earth's climate system, Cambridge University Press, Cambridge, https://doi.org/10.1017/CBO9781139583909, 2014.

Basurah, H. M.: Auroras in Arabian Peninsula, J. King Saud. Univ. Sci., 22, 195-200, https://doi.org/10.4197/Sci.22-2.15, 2010.

Bayliffe, B. G. and Rawes, J. A.: Extracts from the Journal and Ship's Log of the Hon. Company's Ship Repulse (British Library Ref: L/MAR/B/51F.), available at: http://www.heicshipslogs.co. uk/logs/h022.htm\#76 (last access: 30 May 2021), 2016.

Bohren, C. F. and Huffman, D. R.: Absorption and scattering of light by small particles, WILEY-VCH Verlag GmbH and Co. KGaA, Weinheim, https://doi.org/10.1002/9783527618156, 2004.

Bolòs, F.: Historial meteorològic i agricola de l'estació, 1831, in: Quintana i Marí, A., Assaig Sobre El Clima D’Olot, Servei Meteorologic De Catalunya, Notes D’Estudi, No. 69, Casa D’Assistència President Macià, Barcelona, 62-63, 1938.

Breen, P. H.: Nat Turner's Revolt: Rebellion and Response in Southampton County, Virginia, Ph. D. dissertation, University of Georgia, Athens, Georgia, 2005.

Brönnimann, S., Franke, J., Nussbaumer, S. U., Zumbühl, H. J., Steiner, D., Trachsel, M., Hegerl, G. C., Schurer, A., Worni, M., Malik, A., Flückiger, J., and Raible, C. C.: Last phase of the Little Ice Age forced by volcanic eruptions, Nat. Geosci., 12, 650-656, https://doi.org/10.1038/s41561-019-0402-y, 2019.

Bull, G.: Blue sun and moon, Meteorol. Mag, 80, 1-4, 1951.

Burnes, A.: Travels into Bokhara; Being the account of a journey from India to Cabool, Tartary and Persia; Also, Narrative of a Voyage on the Indus, from the sea to Lahore, second edition, volume 1, John Murray, London, 329 pp., 1834. 
Cacciatore, N.: Osservazioni Meteorologiche Fatte Nel Real Osservatorio Di Palermo Nel Mese Di Luglio Dell'Anno 1831, in: Giornale di Scienze Lettere e Arti per La Sicilia, Tomo XXXV. - Anno IX, Luglio, Agosto e Settembre, Tipografia del Giornale Letterario, Palermo, 1831a.

Cacciatore, N.: Osservazioni Meteorologiche Fatte Nel Real Osservatorio Di Palermo Nel Mese Di Agosto Dell'Anno 1831, in: Giornale di Scienze Lettere e Arti per La Sicilia, Tomo XXXV. - Anno IX, Luglio, Agosto e Settembre, Tipografia del Giornale Letterario, Palermo, 1831b.

Cacciatore, N.: Osservazioni Meteorologiche Fatte Nel Real Osservatorio Di Palermo Nel Mese Di Settembre Dell'Anno 1831, in: Giornale di Scienze Lettere e Arti per La Sicilia, Tomo XXXVI. - Anno IX, Ottobre, Novembre e Dicembre, Tipografia del Giornale Letterario, Palermo, 1831c.

Cacciatore, N.: Osservazioni Meteorologiche Fatte Nel Real Osservatorio Di Palermo Nel Mese Di Ottobre Dell'Anno 1831, in: Giornale di Scienze Lettere e Arti per La Sicilia, Tomo XXXVI. - Anno IX, Ottobre, Novembre e Dicembre, Tipografia del Giornale Letterario, Palermo, 1831d.

Camuffo, D. and Enzi, S.: Impact of the clouds of volcanic aerosols in Italy during the last 7 centuries, Nat. Hazards, 11, 135-161, https://doi.org/10.1007/BF00634530, 1995.

Canton Register: "About a week previously, the sun, for several days...", Thursday, 15 September, Vol. 4, No. 18, 1831.

Carpenter, L. G.: The Remarkable Sunsets, Nature, 30, 32-32, https://doi.org/10.1038/030032d0, 1884.

Coltelli, M., Cavallaro, D., D’Anna, G., D’Alessandro, A., Grassa, F., Mangano, G., Patanè, D., and Gresta, S.: Exploring the submarine Graham Bank in the Sicily Channel, Ann. Geophys.-Italy, 59, 2, https://doi.org/10.4401/ag-6929, 2016

Colton, C.: Four Years in Great Britain, 1831-1835, Vol. 1, Harper and Brothers, New York, 312 pp., 1835.

Compo, G. P., Whitaker, J. S., Sardeshmukh, P. D., Matsui, N., Allan, R. J., Yin, X., Gleason, B. E., Vose, R. S., Rutledge, G., Bessemoulin, P., Brönnimann, S., Brunet, M., Crouthamel, R. I., Grant, A. N., Groisman, P. Y., Jones, P. D., Kruk, M. C., Kruger, A. C., Marshall, G. J., Maugeri, M., Mok, H. Y., Nordli, Ø., Ross, T. F., Trigo, R. M., Wang, X. L., Woodruff, S. D., and Worley, S. J.: The Twentieth Century Reanalysis Project, Q. J. Roy. Meteor. Soc., 137, 1-28, https://doi.org/10.1002/qj.776, 2011.

Costa, A. J., Suzuki, Y., and Koyaguchi, T.: Understanding the plume dynamics of explosive super-eruptions, Nat. Commun., 9, 654, https://doi.org/10.1038/s41467-018-02901-0, 2018.

Crosweller, H. S., Arora, B., Brown, S. K., Cottrell, E., Deligne, N. I., Guerrero, N. O., Hobbs, L., Kiyosugi, K., Loughlin, S. C., Lowndes, J., Nayembil, M., Siebert, L., Sparks, R. S. J., Takarada, S., and Venzke, E.: Global database on large magnitude explosive volcanic eruptions (LaMEVE), J. Appl. Volcanol., 1, 4, https://doi.org/10.1186/2191-5040-1-4, 2012.

Davy, J.: X. Further notice of the new volcano in the Mediterranean, Phil. Trans. R. Soc., 122, 251-253, https://doi.org/10.1098/rstl.1832.0011, 1832.

Dean, R. D.: Graham Island, Charles Lyell, and the Craters of Elevation Controversy, Isis, 71, 571-588, https://doi.org/10.1086/352593, 1980.

DeKay, J. E.: Sketches of Turkey in 1831 and 1832, J. and J. Harper, New York, 1833.
Devine, J. D., Sigurdsson, H., Davis, A. N., and Self, S.: Estimates of sulfur and chlorine yield to the atmosphere from volcanic eruptions and potential climatic effects, J. Geophys. Res.-Solid Earth, 89, 6309-6325, https://doi.org/10.1029/JB089iB07p06309, 1984.

Du Bois de Montpéreux, F.: Voyage autour du Caucase, chez les Tcherkesses et les Abkhases, en Colchide, en Géorgie en Arménie et en Crimée, Librairie de Gide, Paris, volume 1, 435 pp., 1839.

Duffield, W. A., Tilling, R. I., and Canul, R.: Geology of El Chichon volcano, Chiapas, Mexico, J. Volcanol. Geoth. Res., 20, 117-132, https://doi.org/10.1016/0377-0273(84)90069-6, 1984.

Dufour, L.: Communication to the 22 August 1831 meeting of the Académie des Sciences, in: Journal de Chimie Médicale, de Pharmacie et de Toxicologie, Tome VII, Chez Béchet Jeune, Paris, 1831.

Ehlers, K., Chakrabarty, R., and Moosmüller, H.: Blue moons and Martian sunsets, Appl. Optics, 53, 1808-1819, 2014.

El Correo: "Provincia de Avila...", Viernes, 26 Agosto, No. 489, p. 4, 1831.

Estrella, C.: Fenómeno Meteorológico, in: El Correo, Miércoles, 24 August, No. 488, p. 3, 1831.

Francis, P. and Oppenheimer, C.: Volcanoes, Second edition, 521 pages, Oxford University Press, Oxford, ISBN 978-0-19925469-9, 2004.

Gao, C., Robock, A., and Ammann, C.: Volcanic forcing of climate over the past 1500 years: An improved ice core-based index for climate models, J. Geophys. Res.-Atmos., 113, D23111, https://doi.org/10.1029/2008JD010239, 2008.

Garrison, C. S., Kilburn, C. R. J., and Edwards, S. J.: The 1831 eruption of Babuyan Claro that never happened: has the source of one of the largest volcanic climate forcing events of the nineteenth century been misattributed?, J. Appl. Volcanol., 7, 8, https://doi.org/10.1186/s13617-018-0078-9, 2018.

Gazzetta di Firenze: "Granducato di Toscana...", Martedi, 16 Agosto, No. 98, p. 3, 1831.

Gazzetta di Genova: "Fenomeni celesti...", Sabato, 13 Agosto, No. 65,1831

Gemmellaro, C.: Relazione dei fenomeni del Nuovo Volcano sorto dal mare fra la costa di Sicilia e l'isola di Pantellaria nel mese di luglio 1831, Pastore, Catania, 1831.

Georgia Messenger: "Solar Phenomenon...", Saturday, 27 August, Vol. 9, No. 25, p. 2, Macon, 1831.

Global Volcanism Program: Volcanoes of the World, v. 4.10.0 (14 May 2021), edited by: Venzke, E., Smithsonian Institution, Washington, 2013.

Gouhier, M. and Paris, R.: $\mathrm{SO}_{2}$ and tephra emissions during the December 22, 2018 Anak Krakatau flank-collapse eruption, Volcanica, 2, 91-103, https://doi.org/10.30909/vol.02.02.91103, 2019.

Groves, A.: Journal of a Residence at Baghdad during the years 1830 and 1831, James Nisbet, London, 1832.

Guidoboni, E.: History and Volcanology: Dialogue Overdue? The Case of a False Eruption in Medieval Italy, Eos, Trans. AGU, 91, 231, https://doi.org/10.1029/2010EO260002, 2010.

Hallowell, B.: Communication to the Washington National Intelligencer, in: Washington National Intelligencer, Monday, $24 \mathrm{Au}-$ gust, 3 pp., 1831. 
Hamilton, K. and Sakazaki, T.: Exploring the "prehistory" of the equatorial stratosphere with observations following major volcanic eruptions, Weather, 73, 154-159, https://doi.org/10.1002/wea.3043, 2018.

Harvey, A. W.: Communication to Sir David Brewster, 1839, in: British Association for the Advancement of Science (BAAS), Report of the Tenth Meeting (Held in Glasgow in August 1840), John Murray, London, 11 p., 1841.

Hazard's Register of Pennsylvania: 17 September, No. 194, Vol. 8, p. $192,1831$.

Hess, M.: "I was in the town of Trenton, State of Tennessee...", 1831, in: Roberson, D. M.: Margaret Daveiss Hess - The First Woman to Plead A Court Case in the U.S., Ansearchin News Tennessee Genealogical Magazine, 47, 2, 3-8, 2000.

Hoffman, F.: Intorno al nuovo vulcano presso la città di Sciacca: lettera del signor Federigo Hoffmann al ducca di Serradifalco, Presso La Reale Stamperia, Palermo, 13 p., https://doi.org/10.3931/e-rara-11173, 1831.

Horner, G. R. B.: An Account of the Cholera which occurred on board the United States' ship John Adams, 1831, Am. J. Med. Sci., Vol. IX, 257-263, Carey and Lea, Philadelphia, 1831.

Horvath, H., Metzig, G., Preining, O., and Pueschel, R. F.: Observation of a blue sun over new Mexico, U.S.A., on 19 April 1991, Atmos. Environ., 28, 621-630, https://doi.org/10.1016/13522310(94)90039-6, 1994.

Hough, F. B.: Results of a series of meteorological observations, made in obedience to instructions from the Regents of the University, at sundry academies in the state of New York, from 1826 to 1850 inclusive, p. xiv, Weed, Parsons and Company, Albany, 1855.

Inaba, M., Tarnishing of Silver: A short review, Victoria and Albert Museum Conservation Journal, No. 18, 1996.

Jacquemont, V.: Letters from India; Describing a journey in the British Dominions of India, Tibet, Lahore and Cashmere, Vol 1., edited by: Churton, E., London, 409 pp., 1834.

Journal de Genève: "Apparence Singuliere qu'a presente le soleil...", Jeudi, 22 Septembre, p. 168, 1831.

Khaykin, S., Legras, B., Bucci, S., Sellitto, P., Isaksen, L., Tencé, F., Bekki, S., Bourassa, A., Rieger, L., Zawada, D., Jumelet, J., and Godin-Beekmann, S.: The 2019/20 Australian wildfires generated a persistent smoke-charged vortex rising up to $35 \mathrm{~km}$ altitude, Commun. Earth Environ., 1, 22, https://doi.org/10.1038/s43247-020-00022-5, 2020.

Kiessling, J.: Untersuchungen über Dämmerungserscheinungen: zur Erklärung der nach dem Krakatau-Ausbruch beobachteten atmosphärisch-optischen Störung, L. Voss, Hamburg und Leipzig, 172 pp., 1888.

Krueger, A., Krotkov, N., and Carn, S.: El Chichon: The genesis of volcanic sulfur dioxide monitoring from space, J. Volcanol. Geoth. Res., 175, 408-414, https://doi.org/10.1016/j.jvolgeores.2008.02.026, 2008.

La Mer, V. K. and Kerker, M.: Light Scattered by Particles, Sci. Am., 188, 69-77, 1953.

Laurent, P. E.: Recollections of a Classical Tour Through Various Parts of Greece, Turkey and Italy, Vol. 2, G. and W. B. Whittaker, London, 1821.

L'Abeille: "Nouvelle-Orleans, 17 Août. L'almanach de la Havane...', Jeudi, 18 Août, p. 1, New Orleans, 1831.
London and Paris Observer: "Arts and Sciences, Meetings of Scientific Bodies...", 328, 28 August, p. 558, Paris, 1831.

London Morning Post: "New York, Aug. 18 - Solar Phenomenon...", Tuesday, 27 September 1831.

Luhr, J. F., Carmichael, I. S. E., and Varekamp, J. C.: The 1982 eruptions of El Chichón Volcano, Chiapas, Mexico: Mineralogy and petrology of the anhydrite bearing pumices, J. Volcanol. Geoth. Res., 23, 69-108, https://doi.org/10.1016/0377-0273(84)90057X, 1984.

Luhr, J. F.: Primary igneous anhydrite: Progress since its recognition in the 1982 El Chichón trachyandesite, 175, 394-407, https://doi.org/10.1016/j.jvolgeores.2008.02.016, 2008.

Mather, T. A., Pyle, D. M., and Oppenheimer, C.: Tropospheric Volcanic Aerosol, in: Volcanism and the Earth's Atmosphere, 189212, https://doi.org/10.1029/139GM12, 2004.

Mathieu: Communication to the 29 August 1831 meeting of the Académie des Sciences, in: Mémorial Encyclopédique et Progressif des Connaissances Humaines, October, No. 10, 1831.

Meinel, A. and Meinel, M.: Sunsets, twilights, and evening skies, Cambridge University Press, Cambridge, 1991.

Mie, G.: Beiträge zur Optik trüber Medien, speziell kolloidaler Metallösungen, Ann. Phys., 330, 377-445, https://doi.org/10.1002/andp.19083300302, 1908.

Minnaert, M.: The Nature of Light and Colour in the Open Air, Dover Publications, 362 pp., 1954.

Mobile Register: "Singular Phenomena...", 17 August 1831, in: American Journal of Science and Arts, January, Vol. XXI, p. 198, 1832.

Newhall, C. G. and Self, S.: The volcanic explosivity index (VEI) an estimate of explosive magnitude for historical volcanism, J. Geophys. Res.-Oceans, 87, 1231-1238, https://doi.org/10.1029/JC087iC02p01231, 1982.

New York Evening Post: "Pittsburgh (Penn.) Aug 12. Singular appearance...", Wednesday, 17 August, No. 9050, p.2, 1831a.

New York Evening Post: “Atmospheric Phenomenon...”, Tuesday, 16 August, 9049, p. 2, 1831 b.

Niles' Weekly Register: "The Solar Phenomena...”, in: Niles' Weekly Register, 1 October, Fourth Series, No. 5, Vol. V, Baltimore, 1831.

Oppenheimer, C., Scaillet, B., and Martin, R. S.: Sulfur degassing from volcanoes: source conditions, surveillance, plume chemistry and earth system impacts, Rev. Mineral Geochem., 73, 363421, https://doi.org/10.2138/rmg.2011.73.13, 2011.

Penndorf, R.: On the phenomenon of the colored sun, especially the "blue" sun of September 1950, Geophysical Research Papers No. 20, Air Force Cambridge Research Center, Cambridge, Massachusetts, 1953.

Philosophical Magazine: Meteorological Observations for August 1831, July - December, Vol. X, 318-320, 1831.

Porch, W. M.: Blue moons and large fires, App. Opt., 28, 17781784, 1989.

Porter, D.: Constantinople and its Environs in a Series of Letters, Harper and Brothers, New York, 1835.

Poussou: Lettre de M. Poussou, supérieur de la mission des Lazaristes à Damas, à M. Etienne, procureur-général de la congregation des Lazaristes, 1831, in: Annales de la Propagation de la Foi, Tome Cinquante-Troisieme, 541 pp. et seq, L'Éditeur des Annales, Lyon, 1881. 
Prata, A. T., Folch, A., Prata, A. J., Biondi, R., Brenot, H., Cimarelli, C., Corradini, S., Lapierre, J., and Costa, A.: Anak Krakatau triggers volcanic freezer in the upper troposphere, Sci. Rep., 10, 3584, https://doi.org/10.1038/s41598-020-60465-w, 2020.

Pyle, D. M. and Barclay, J.: Historical records of volcanic eruptions deserve more attention, Nature Reviews Earth and Environment, 1, 183-184, 2020.

Rampino, M. R. and Self, S.: Sulphur-rich volcanic eruptions and stratospheric aerosols, Nature, 310, 677-679, https://doi.org/10.1038/310677a0, 1984.

Randel, W. J.: Middle Atmosphere/Zonal Mean Climatology, in: Encyclopedia of atmospheric sciences, edited by: Holton, J. R., Curry, J. A., and Pyle, J. A., Academic Press, 1358-1365, https://doi.org/10.1016/B0-12-227090-8/00227-X, 2003.

Reid, W.: Communication to Sir David Brewster, 1839, in: British Association for the Advancement of Science (BAAS), Report of the Tenth Meeting (Held in Glasgow in August 1840), John Murray, London, 10 p., 1841.

Retalis, A. and Cartalis, C.: Definition of the tropopause height in the South-Eastern Mediterranean region, Toxicol. Environ. Chem., 58, 259-267, https://doi.org/10.1080/02772249709358415, 1997.

Riccò, A.: L'île Ferdinandea, le soleil bleu et les crépuscules rouges de 1831, in: Compt. Rend. Hebd. Ac. Sc., Vol. CII, 1060-1063, Paris, 1886.

Robertson, A., Overpeck, J., Rind, D., Mosley-Thompson, E., Zielinski, G., Lean, J., Koch, D., Penner, J., Tegen, I., and Healy, R.: Hypothesized climate forcing time series for the last 500 years, J. Geophys Res.-Atmos., 106, 14783-14803, https://doi.org/10.1029/2000JD900469, 2001.

Robock, A.: Volcanic eruptions and climate, Rev. Geophys., 38, 191-219, https://doi.org/10.1029/1998RG000054, 2000.

Roulin, F. D.: Communication to the 29 August 1831 meeting of the Académie des Sciences, in: Mémorial Encyclopédique et Progressif des Connaissances Humaines, October, No. 10, 1831.

Rozet, C. A.: Relation de la Guerre d'Afrique pendant les années 1830 et 1831, Volume 2, Chez Firman, Didot, Frères, Libraires, Paris, 1832.

Rozet, C. A.: Voyage dans la Régence d'Alger, 1, 155-157, Arthus Bertrand, Paris, 1833.

Russo Ferrugia, S.: Storia dell'Isola Ferdinandea, Trapani, 60 pp., 1831.

Savannah Republican: "Remarkable state of the Atmosphere...", Thursday, 18 August, Vol. XXVIII, 168, p. 2, 1831.

Schaefer, B. E.: Astronomy and the limits of vision, Vistas Astron., 36, 311-361, https://doi.org/10.1016/0083-6656(93)90113-X, 1993.

Schomburgk, R. H.: The History of Barbados, Longman, Brown, Green and Longmans, London, 722 pp., 1848.

Schwabe, H. F.: Beobachtungen an Sonne, Planeten (Erdatmosphäre) und Kometen während des Jahres 1831, in: Archiv für die gesammte Naturlehre, edited by: Kastner, K. W. G., Johann Adam Stein, Nürnberg, 22, 393-395, 1831.

Self, S., Rampino, M. R., and Carr, M. J.: A reappraisal of the 1835 eruption of Cosigüina and its atmospheric impact, B. Volcanol., 52, 57-65, https://doi.org/10.1007/BF00641387, 1989.

Self, S., Zhao, J. X., Holasek, R. E., Torres, R. C., and King, A. J.: The atmospheric impact of the 1991 Mount Pinatubo eruption, in: Fire and Mud: Eruptions and Lahars of Mount Pinatubo,
Philippine Institute of Volcanology and Seismology and the University of Washington Press, edited by: Newhall, C. G. and Punongbayan, R. S., Philippines, 1126 pp., 1993.

Sigl, M., McConnell, J. R., Layman, L., Maselli, O., McGwire, K., Pasteris, D., Dahl-Jensen, D., Steffensen, J. P., Vinther, B., Edwards, R., Mulvaney, R., and Kipfstuhl, S.: A new bipolar ice core record of volcanism from WAIS Divide and NEEM and implications for climate forcing of the last 2000 years, J. Geophys Res.-Atmos., 118, 1151-1169, https://doi.org/10.1029/2012JD018603, 2013.

Slivinski, L. C., Compo, G. P., Whitaker, J. S., Sardeshmukh, P. D., Giese, B. S., McColl, C., Allan, R., Yin, X., Vose, R., Titchner, H., Kennedy, J., Spencer, L. J., Ashcroft, L., Brönnimann, S., Brunet, M., Camuffo, D., Cornes, R., Cram, T. A., Crouthamel, R., Domínguez-Castro, F., Freeman, J. E., Gergis, J., Hawkins, E., Jones, P. D., Jourdain, S., Kaplan, A., Kubota, H., Blancq, F. L., Lee, T.-C., Lorrey, A., Luterbacher, J., Maugeri, M., Mock, C. J., Moore, G. W. K., Przybylak, R., Pudmenzky, C., Reason, C., Slonosky, V. C., Smith, C. A., Tinz, B., Trewin, B., Valente, M. A., Wang, X. L., Wilkinson, C., Wood, K., and Wyszyński, P.: Towards a more reliable historical reanalysis: Improvements for version 3 of the Twentieth Century Reanalysis system, Q. J. Roy. Meteor. Soc., 145, 2876-2908, https://doi.org/10.1002/qj.3598, 2019.

Smythe, G. W.: Views and Description of the late Volcanic Island off the coast of Sicily, Joseph Booker, London, 1831.

Spatola, D., Micallef, A., Sulli, A., Basilone, L., Ferreri, R., Basilone, G., Bonanno, A., Pulizzi, M., and Mangano, S.: The Graham Bank (Sicily Channel, central Mediterranean Sea): Seafloor signatures of volcanic and tectonic controls, Geomorphology, 318, 375-389, https://doi.org/10.1016/j.geomorph.2018.07.006, 2018.

Spilliaert, N., Allard, P., Meìtrich, N., and Sobolev, A. V.: Melt inclusion record of the conditions of ascent, degassing, and extrusion of volatile-rich alkali basalt during the powerful 2002 flank eruption of Mount Etna (Italy), J. Geophys. Res., 111, B04203, https://doi.org/10.1029/2005JB003934, 2006.

Stothers, R. B.: Mystery cloud of AD 536, Nature, 307, 344-345, https://doi.org/10.1038/307344a0, 1984a.

Stothers, R. B.: The Great Tambora Eruption in 1815 and Its Aftermath, Science, 224, 1191, https://doi.org/10.1126/science.224.4654.1191, 1984b.

Stothers, R. B.: The great dry fog of 1783, Climatic Change, 32, 79-89, https://doi.org/10.1007/BF00141279, 1996.

Symons, G. (Ed.), Judd, J. W., Strachey, R., Wharton, W. J. L., Evans, F. J., Russell, F. A. R., Archibald, D., and Whipple, G. M.: The Eruption of Krakatoa: And Subsequent Phenomena, Trübner and Company, London, 1888.

Taszarek, M., Brooks, H. E., Czernecki, B., Szuster, P., and Fortuniak, K.: Climatological aspects of convective parameters over Europe: A comparison of ERA-Interim and sounding data, J. Climate, 31, 4281-4308, https://doi.org/10.1175/JCLI-D-170596.1, 2018.

Taylor, T. G.: Result of astronomical observations made at the Honorable the East India Company's Observatory at Madras for the year 1831, Orphan Asylum Press, Madras, 1, 148 pp., 1832.

Tizzani, V. and Croce, G. M. (Eds.): Effemeridi Romane, Volume Primo: 1828-1860, ISBN 978-8-8492-2615-7, Gangemi Editore, Rome, 2015. 
Toohey, M. and Sigl, M.: Volcanic stratospheric sulfur injections and aerosol optical depth from 500 BCE to 1900 CE, Earth Syst. Sci. Data, 9, 809-831, https://doi.org/10.5194/essd-9-809-2017, 2017.

Toohey, M., Krüger, K., Schmidt, H., Timmreck, C., Sigl, M., Stoffel, M., and Wilson, R.: Disproportionately strong climate forcing from extratropical explosive volcanic eruptions, Nat. Geosci., 12, 100-107, https://doi.org/10.1038/s41561-018-0286-2, 2019.

Van de Hulst, H. C.: Light scattering by small particles, Dover Publications, New York, 470 pp., ISBN 978-0-4866-4228-4, 1981.

Washington, H. S.: Submarine eruptions of 1831 and 1891 near Pantelleria, Am. J. Sci., s4-27, 131-150, https://doi.org/10.2475/ajs.s4-27.158.131, 1909.

Washington National Intelligencer: "Norfolk, Aug. 15 - We have all seen the sun of a dusky red or copper color...", 19 August, p. 3, 1831 .

Western Carolinian: "The sun had a very singular appearance...", Monday, 22 August, Vol. XII, No. 585, p. 3, 1831.

White, J. C., Neave, D. A., Rotolo, S. G., and Parker, D. F.: Geochemical constraints on basalt petrogenesis in the Strait of Sicily Rift Zone (Italy): Insights into the importance of short lengthscale mantle heterogeneity, Chem. Geol., 545, 119650, https://doi.org/10.1016/j.chemgeo.2020.119650, 2020.

Whymper, E.: Coloured skies after an eruption of Cotopaxi, Science, ns-3, 99-100, https://doi.org/10.1126/science.ns-3.51.99, 1884.
Wilson, R.: The blue sun of 1950 September, Mon. Not. R. Astron. Soc., 111, 478-489, 1951.

Wullenweber, N., Lange, A., Rozanov, A., and von Savigny, C.: On the phenomenon of the blue sun, Clim. Past, 17, 969-983, https://doi.org/10.5194/cp-17-969-2021, 2021.

Yue, G. K., Poole, L. R., Wang, P.-H., and Chiou, E. W.: Stratospheric aerosol acidity, density, and refractive index deduced from SAGE II and NMC temperature data, J. Geophys. Res.Atmos., 99, 3727-3738, https://doi.org/10.1029/93JD02989, 1994.

Zhang, D.: A compendium of Chinese meteorological records of the last 3000 years, Jiangsu Education House, Nanjing, 2004.

Ziegenbalg, S. B., Brunner, B., Rouchy, J. M., Birgel, D., Pierre, C., Böttcher, M. E., Caruso, A., Immenhauser, A., and Peckmann, J.: Formation of secondary carbonates and native sulphur in sulphate-rich Messinian strata, Sicily, Sediment. Geol., 227, 37-50, https://doi.org/10.1016/j.sedgeo.2010.03.007, 2010.

Zielinski, G. A.: Stratospheric loading and optical depth estimates of explosive volcanism over the last 2100 years derived from the Greenland Ice Sheet Project 2 ice core, J. Geophys. Res.-Atmos., 100, 20937-20955, https://doi.org/10.1029/95JD01751, 1995. 